\title{
NF- $k$ B functions as both a proapoptotic and antiapoptotic regulatory factor within a single cell type
}

\author{
Binhan Lin ${ }^{1}$, Cheryll Williams-Skipp ${ }^{2}$, Yunxia Tao², \\ Mary S. Schleicher ${ }^{3}$, Labertta L. Cano ${ }^{1}$, Richard C. Duke ${ }^{3,4}$ \\ and Robert I. Scheinman ${ }^{\star 1,2,3,5}$ \\ ${ }^{1}$ Program in Toxicology, Denver, Colorado 80262, USA \\ 2 Department of Pharmaceutical Sciences, School of Pharmacy, Denver, \\ Colorado 80262, USA \\ ${ }^{3}$ University of Colorado Cancer Center, Denver, Colorado 80262, USA \\ 4 Department of Medicine and Immunology, School of Medicine, University of \\ Colorado Health Sciences Center, Denver, Colorado 80262, USA \\ ${ }^{5}$ Department of Pharmacology, School of Medicine, University of Colorado \\ Health Sciences Center, Denver, Colorado 80262, USA \\ * correspondence author: Robert I. Scheinman, Program in Toxicology, \\ University of Colorado Cancer Center, Denver, Colorado 80262, USA. tel: (303) \\ 315-6194 fax: (303) 315-0274 e-mail: robert.scheinman@uchsc.edu
}

Received 3.11.98; revised: 5.2.99; accepted: 31.3 .99

Edited by B. Osborne

\begin{abstract}
Recently NF- $k$ B has been shown to have both proapoptotic and antiapoptotic functions. In T cell hybridomas, both $\mathrm{T}$ cell activators and glucocorticoids induce apoptosis. Here we show that blockade of NF- $k$ B activity, using a dominant negative $I_{\kappa} \mathrm{B} \alpha$, has opposite effects on these two apoptotic signals. Treatment with PMA plus ionomycin (P/I) results in the upregulation of Fas Ligand (FasL) and induction of apoptosis. Inhibition of NF- $\kappa$ B activity inhibits the P/I mediated induction of FasL mRNA and decreases the level of apoptosis in these cultures, thus establishing NF- $\kappa \mathrm{B}$ as a proapoptotic factor in this context. Conversely, inhibition of NF- $k$ B confers a tenfold increase in glucocorticoid mediated apoptosis, establishing that $\mathrm{NF}-k \mathrm{~B}$ also functions as an antiapoptotic factor. We conclude that NF- $k B$ is a context-dependent apoptosis regulator. Our data suggests that NF- $\kappa \mathrm{B}$ may function as an antiapoptotic factor in thymocytes while functioning as a proapoptotic factor in mature peripheral $\mathrm{T}$ cells.
\end{abstract}

Keywords: NF- $\kappa$ B; glucocorticoid; Fas Ligand; apoptosis; T cell; AICD; thymic selection

Abbreviations: TCR, T cell receptor; FasL, Fas Ligand; AICD, activation induced cell death; DEX, dexamethasone; $\mathrm{ml} \kappa \mathrm{B} \alpha$, $I_{\kappa} \mathrm{B} \alpha \mathrm{S} 32 / 36 \mathrm{~A}$ mutant; neo, neomycin resistance gene; P/I, PMA plus ionomycin

\section{Introduction}

In order to ensure an appropriately functioning immune system which can distinguish between self and non-self, a number of different signals have evolved to induce lymphocyte apoptosis. Endogenous glucocorticoids are thought to mediate apoptosis of thymocytes with nonfunctional T cell receptors (TCR) during positive selection. ${ }^{1}$ In turn, apoptosis, initiated by activation of the TCR, plays an important role in negative selection of thymocytes as well as deletion of peripheral T cells. ${ }^{2}$ Understanding the molecular basis for $\mathrm{T}$ cell apoptosis has been greatly aided by the development of cell culture systems, such as $\mathrm{T}$ cell hybridomas, amenable to biochemical and genetic manipulations. Ashwell and colleagues were the first to demonstrate activation induced cell cycle arrest followed by cell death. ${ }^{3,4}$ This activation induced cell death (AICD) was subsequently characterized as apoptosis. $^{5-7}$ Interestingly, simultaneous exposure of $\mathrm{T}$ cell hybridomas to glucocorticoids and to activation results in the mutual inhibition of these two apoptotic pathways..$^{8,9}$ Indeed this observation led to the discovery that glucocorticoids are produced in the fetal thymus and function to induce thymocyte apoptosis during selection. ${ }^{10,11}$ In addition this work led to the observation that glucocorticoids inhibit anti-CD3 mediated induction of Fas Ligand (FasL) expression. $^{12}$

While glucocorticoid mediated thymocyte apoptosis remains largely undefined, AICD in peripheral $T$ cells has been intensively studied. Analysis of the Ipr and gld mutations, both resulting in a lymphoproliferative disorder primarily inhibiting peripheral $T$ cell deletion, ${ }^{13,14}$ has resulted in the association of this phenotype with the dysfunction of the Fas receptor (Fas) and the FasL respectively. ${ }^{15}$ Analysis of AICD in several culture models including $\mathrm{T}$ cell hybridomas subsequently identified Fas/ FasL interactions as important for the induction of apoptosis. $^{16-18}$ Fas is a member of the TNF receptor family which includes TNFR1, TNFR2, as well as receptors for lymphotoxin- $\beta$, CD27, CD30, CD40 and others. ${ }^{15} \mathrm{~A}$ subgroup within this family which includes Fas and TNFR1 have a conserved cytoplasmic domain, referred to as the death domain, which is necessary for initiation of apoptosis. A growing number of proteins have been identified which interact with the Fas and TNFR1 death domains. ${ }^{19-21}$ Upon engagement of the FasL, Fas associates with FADD (MORT1) which itself contains a C-terminal death domain. $^{22,23}$ The N-terminus, which contains the death effector domain (DED) interacts with pro-caspase 8 (MACH, FLICE), ultimately resulting in the activation of a caspase cascade which mediates apoptosis. ${ }^{24,25}$ The death domain of TNFR1 associates with TRADD and with RIP. ${ }^{26,27}$ TRADD, in turn, interacts with FADD, suggesting that the apoptotic signals initiated by FasL and TNF $\alpha$ ultimately converge. ${ }^{28}$

TRADD also induces the transcription factor NF- $\kappa$ B by interacting with TRAF proteins. ${ }^{29} \mathrm{NF}-\kappa \mathrm{B}$ plays an important role in the activation of responses to immune challenge, inflammation, and cellular stress. ${ }^{30,31}$ In addition, NF- $\kappa \mathrm{B}$ has recently been shown to play an important and varied 
role in the regulation of apoptosis. NF- $\kappa \mathrm{B}$ is comprised of a heterodimeric complex of a $50-\mathrm{kDal}$ subunit (p50, NF- $\kappa \mathrm{B} 1$ ) and a 65-kDal subunit (p65, RelA) which is complexed in the cytoplasm with a family of inhibitors termed $\mathrm{I}_{\kappa} \mathrm{Bs} .^{30,31}$ The NF- $\kappa$ B p50 and RelA subunits, along with p52 (NF$\kappa \mathrm{B} 2$, lyt-10) and RelB, share homology with the products of the c-rel oncogene and Drosophila maternal effects gene, Dorsal, thus forming the Rel/NF- $\kappa \mathrm{B}$ gene family. ${ }^{30,31}$ The $\mathrm{N}$ terminal region of homology, termed the Rel homology domain, mediates dimerization, DNA binding, nuclear localization, and interaction with $I \kappa \mathrm{B}$ through $\mid \kappa \mathrm{B}$ 's ankyrin repeat domain. These NF- $\kappa \mathrm{B}$ genes are able to homodimerize and heterodimerize to form a large number of NF$\kappa \mathrm{B}$-like activities which have been shown to have differing affinities for various NF- $\kappa$ B response elements. ${ }^{32}$ Numerous stimuli including mitogens, cytokines, reactive oxygen intermediates, LPS, and viral infection result in the activation of $\mathrm{NF}-\kappa \mathrm{B}$. In many instances this is thought to involve the activation of the $\mathrm{I}_{\kappa} \mathrm{B}$ kinase $(\mathrm{IKK})$ complex which then phosphorylates $\mid \kappa \mathrm{B}$, resulting in its ubiquitination and degradation by the proteosome. ${ }^{33-35}$ Dissociation of $\mathrm{I}_{\kappa} \mathrm{B}$ from NF- $\kappa$ B allows NF- $\kappa$ B to translocate to the nucleus. Thus NF- $\kappa$ B-like activities comprise a complex web of interrelated factors which can regulate subsets of a large number of genes in response to specific stimuli.

In a number of systems, NF- $\kappa \mathrm{B}$ has been demonstrated to have an antiapoptotic function. Knockout of relA results in an embryonic lethal phenotype which was found to be caused by TNF $\alpha$ induced apoptosis within the fetal liver. ${ }^{36}$ Subsequently, it was demonstrated that reintroduction of relA to immortalized hepatocytes derived from these animals protected these cells from TNF $\alpha$ induced apoptosis. ${ }^{37} \mathrm{NF}-\kappa \mathrm{B}$ has also been shown to inhibit TNF $\alpha$ mediated apoptosis in primary rat and human fibroblasts as well as Jurkat T cells and the T24 human bladder carcinoma line ${ }^{38}$ and in MCF7 breast cancer cells. ${ }^{39}$ In addition, NF- $\kappa$ B has been shown to play a role in apoptosis mediated by engagement of PPAR $\alpha$ and PPAR $\gamma$ in both TNF $\alpha$ stimulated and in unstimulated differentiated macrophages. ${ }^{40} \mathrm{NF}-\kappa \mathrm{B}$ has also been found to protect ras transformed tumor cells from apoptosis induced by chemotherapy. ${ }^{41,42}$ Several NF$\kappa \mathrm{B}$ responsive antiapoptotic genes which may play a role in this process have subsequently been identified and include clAP1, clAP2, TRAF1 and TRAF2. ${ }^{43}$ In addition IEXL-1 has been identified as an $\mathrm{NF}-\kappa \mathrm{B}$ responsive antiapoptotic gene $^{44}$ however the mechanism by which this protein blocks apoptosis is unclear. Regulation of NF- $\kappa \mathrm{B}$ has also been shown to play a role in both TGF $\beta$ mediated induction of $\mathrm{B}$ cell apoptosis through induction of $\mathrm{I}_{\kappa} \mathrm{B} \alpha$ expression ${ }^{45}$ as well as in CD40L rescue from apoptosis through decreased $\mathrm{I} \kappa \mathrm{B} \alpha$ expression. ${ }^{46}$ Here $\mathrm{NF}-\kappa \mathrm{B}$ functions to stimulate expression of c-myc, a factor necessary for B cell survival. Thus NF- $\kappa$ B plays an antiapoptotic role in a variety of systems and activates different subsets of antiapoptotic genes within these systems.

Evidence has also accumulated implicating NF- $\kappa \mathrm{B}$ in the induction of apoptosis. Studies have correlated induction of apoptosis with activation of $\mathrm{NF}-\kappa \mathrm{B}$ in a wide variety of systems including avian embryonic development, ${ }^{47}$ ceramide activated osteoblasts ${ }^{48}$ and dopaminergic neurons derived from Parkinson disease patients. ${ }^{49}$ With the development of inhibitors of $\mathrm{NF}-\kappa \mathrm{B}$ function, more definitive evidence has since been generated. Alphavirus induction of apoptosis in a prostate carcinoma line was shown to be inhibited by inhibiting NF- $\kappa$ B activity using binding site decoys. ${ }^{50}$ Interestingly, viral induction of apoptosis in a neuroblastoma line was not affected by inhibition of NF- $\kappa \mathrm{B}$, underscoring the cell specificity of NF$\kappa \mathrm{B}$ mediated regulation of apoptosis. Similarly, Denge virus induction of apoptosis in hepatocytes could be blocked using NF- $\kappa \mathrm{B}$ decoys. ${ }^{51}$ Within the CNS, pathological activation of glutamate receptors and the subsequent generation of oxygen radicals may be a pathway leading to an apoptosis-like process of neurodegeneration common to several disease states. ${ }^{52}$ Evidence for NF- $\kappa$ B involvement came from the observation that aspirin both acts as a neuroprotective agent and functions to inhibit glutamate receptor mediated activation of $\mathrm{NF}-\kappa \mathrm{B} .{ }^{53}$ More recent studies then confirmed the role of $N F-\kappa B$ by showing that a cell permeable NF- $\kappa$ B blocking peptide inhibited quinolinic acid-induced striatal cell death. ${ }^{54}$ Thus the role of NF- $\kappa$ B as a regulator of apoptosis is complex and tissue specific.

$\mathrm{NF}-\kappa \mathrm{B}$ activity has been detected in both thymocytes and mature $\mathrm{T}$ cells. ${ }^{30,31}$ Studies of specific NF- $\kappa \mathrm{B}$ subunits expressed during thymocyte positive selection have identified a strong upregulation of c-Rel mRNA and an increase in the constitutive activity of several forms of NF$\kappa \mathrm{B} .{ }^{55}$ In mature peripheral $\mathrm{T}$ cells representing murine Th1 and Th2 populations, NF- $\kappa \mathrm{B}$ activity was found to be much decreased in the Th2 population as compared to Th1 and Th0 populations. Thus NF- $\kappa \mathrm{B}$ changes both in subunit composition and activity level during $\mathrm{T}$ cell development. Nuclear translocation of NF- $\kappa \mathrm{B}$ in mature peripheral T cells requires both engagement of the TCR as well as a costimulatory signal. In turn, $T$ cell activation requires the de novo transcription of $\mathrm{IL}-2$, which is regulated by $\mathrm{NF}-\kappa \mathrm{B}$, NFAT, and AP-1 activities. ${ }^{56,57}$ Knockout of specific NF- $\kappa$ B genes results in reduced peripheral $\mathrm{T}$ cell activation and proliferation, but little change in thymic selection. ${ }^{58}$ Recently, through the study of $\mathrm{NF}-\kappa \mathrm{B}$ activation via $I_{\kappa} \mathrm{Ba}$ phosphorylation, serines at positions 32 and 36 were identified as critical targets for IKK mediated activation. ${ }^{59,60}$ An $1 \kappa \mathrm{B} \alpha$ mutant was then developed replacing serines 32 and 36 with alanines. This mutant binds to NF$\kappa \mathrm{B}$ but cannot release it in response to stimulation and thus effectively inhibits all inducible forms of NF- $\kappa$ B activity. In contrast to the knockout experiments, direction of the expression of this mutant $\mathrm{I}_{\kappa} \mathrm{B} \alpha(\mathrm{ml} \kappa \mathrm{B} \alpha)$ to thymocytes of transgenic mice, results in a significant loss of $T$ cells which survive thymic selection as well as a relative increase in the ratio of CD4 to CD8 single positive $T$ cells, ${ }^{61}$ suggesting that $\mathrm{NF}-\kappa \mathrm{B}$ plays an important role in the selection process and that different forms of NF- $\kappa$ B may be able to substitute for each other. Hence NF- $\kappa$ B plays a role both in the processes of thymic selection as well as peripheral $\mathrm{T}$ cell activation.

Recently, it has been shown that glucocorticoids can inhibit NF- $\kappa$ B activity through direct association of GR with NF- $\kappa \mathrm{B}$ subunits, ${ }^{62-64}$ through induction of $\mathrm{I} \kappa \mathrm{B} \alpha$ expression, ${ }^{65,66}$ and through competition for the co-activator 
protein, $\mathrm{CBP} / \mathrm{p} 300 .^{67}$ This interaction between two transcription factors, both of which function to regulate apoptosis, has led us to hypothesize that NF- $\kappa \mathrm{B}$ may play an important role in modulating glucocorticoid mediated apoptosis as well as AICD. Here we demonstrate that inhibition of NF- $\kappa$ B leads to loss of the induction of FasL expression and reduced apoptosis while simultaneously increasing the sensitivity of these cells to DEX mediated apoptosis. Thus NF- $\kappa \mathrm{B}$ has both proapoptotic and antiapoptotic functions within a single cell type.

\section{Results}

\section{Inhibition of NF- $\kappa$ B in $\mathbf{T}$ cell hybridomas}

As mentioned above, $I_{\kappa} \mathrm{B} \alpha$ phosphorylation is essential for $\mathrm{NF}-\kappa \mathrm{B}$ activation. An $\mathrm{I}_{\kappa} \mathrm{B} \alpha$ mutant in which serines in positions 32 and 36 have been substituted for alanines $\left(\mathrm{ml}_{\kappa} \mathrm{B} \alpha\right)$ has been developed by several laboratories to function as a strong dominant negative inhibitor of NF- $\kappa \mathrm{B} .{ }^{59,60}$ We introduced this $\mathrm{I} \kappa \mathrm{B} \alpha$ mutant into the $\mathrm{T}$ cell hybridoma lines, D011.10 and 2B4.11 by electroporation of either pCMV4-I $\kappa \mathrm{B} \alpha \mathrm{S} 32 / 36 \mathrm{~A}$ or pCMV4-FLAG- $I_{\kappa} \mathrm{B} \alpha \mathrm{S} 32 / 36 \mathrm{~A}$ (gifts of $\mathrm{D}$. Ballard) in the presence of the neomycin resistance gene and established a number of independent stable $\mathrm{ml} \kappa \mathrm{B} \alpha$ expressing lines as described in Materials and Methods. The neomycin resistance gene (neo) was also transfected alone to create several control lines. Presence of the FLAG epitope has no effect on $\mathrm{ml} \kappa \mathrm{B} \alpha$ function (D. Ballard, personal communication) but allows for the measurement of transgene detection apart from endogenous $\mathrm{I} \kappa \mathrm{B} \alpha$ expression. Figure 1 shows a representative Western blot analyzing the expression of the FLAG epitope tagged transgene in several 2B4.11 lines. The transgene migrates just below the $41.8 \mathrm{kDal}$ molecular weight marker as expected (Figure 1). Lines $2 \mathrm{P}, 4 \mathrm{P}$, and $5 \mathrm{P}$ are representative of high FLAG epitope expression while lines $3 \mathrm{P}$ and $5 \mathrm{M}$ are representative of intermediate FLAG epitope expression (Figure 1). Lines $3 \mathrm{M}$ and $4 \mathrm{M}$ have very low, but detectable, transgene expression while parental 2B4.11 cells did not contain the FLAG epitope (Figure 1). Neo expressors generated a pattern identical to parental lines (data not shown).

We then wanted to characterize NF- $\kappa \mathrm{B}$ expression in these cells. 2B4.11 cultures were treated with PMA and ionomycin (P/I) and nuclear extracts prepared as described in Materials and Methods. EMSA analysis was then performed using an NF- $\kappa \mathrm{B}$ site, found on the FasL

\section{Par. 2P $5 P \quad 5 M \quad 4 P \quad 4 M \quad 3 P \quad 3 M$}

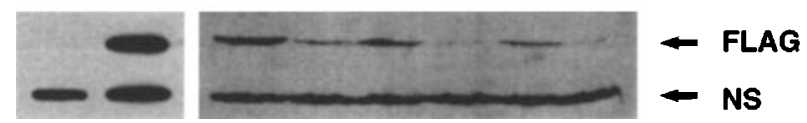

Figure $12 \mathrm{~B} 4.11 \mathrm{~T}$ cell lines expressing various levels of FLAG-tagged $\mathrm{ml} \kappa \mathrm{B}$. Cytosolic extracts of the parental 2B4.11 line and various 2B4.11 lines expressing a FLAG-tagged $\mathrm{ml} \kappa \mathrm{B} \alpha$ transgene were examined by FLAG antibody Western and visualized by ECL. NS: non-specific binding. Lines $2 \mathrm{P}, 3 \mathrm{P}, 4 \mathrm{P}$, and $5 \mathrm{P}$ were isolated from one transfection experiment. Similarly, lines $3 \mathrm{M}, 4 \mathrm{M}$, and $5 \mathrm{M}$ were isolated from a separate transfection experiment promoter, as a probe. As shown in Figure 2A, treatment of parental 2B4.11 cells with $P / I$ resulted in the up regulation of a protein/DNA complex which was present in minor amounts in non-activated cells. This complex was effectively blocked by a 20-fold excess of unlabeled DNA corresponding to an NF- $\kappa \mathrm{B}$ site derived from the murine $\mathrm{H} 2-\mathrm{K}^{\mathrm{b}} \mathrm{MHC}$ class I promoter $(\kappa \mathrm{B})$. In contrast, a 20 -fold excess of a double point mutant of the $\mathrm{H} 2-\mathrm{K}^{\mathrm{b}} \mathrm{NF}-\kappa \mathrm{B}$ site $(\mathrm{m} \kappa \mathrm{B})$ was unable to effectively block the formation of the complex. The FasL NF$\kappa \mathrm{B}$ site (FL) also competed against self, as expected. To further confirm the identity of this DNA binding protein, we performed a supershift experiment. As shown in Figure 2B, pretreatment with antisera specific for relA(p65) partially supershifted the complex while an antisera specific for p50 blocked DNA binding, suggesting that the complex contains of heterodimers of relA and p50. While the presence of other $\mathrm{NF}-\kappa \mathrm{B}$ subunits in this complex has yet to be determined, it is clear from the data presented that this complex corresponds to $\mathrm{NF}-\kappa \mathrm{B}$. We then tested the ability of the $\mathrm{ml} \kappa \mathrm{B} \alpha$ transgene to block the nuclear translocation of NF$\kappa \mathrm{B}$. As shown in Figure $2 \mathrm{C}, \mathrm{NF}-\kappa \mathrm{B}$ DNA binding is induced upon treatment of a Neo P/I expressing line. Induction of NF$\kappa \mathrm{B}$ binding in the 2B4.11 4P line is greatly decreased however by overexpression of the transgene (compare Figure 1 and Figure 2C). Interestingly, a low $\mathrm{ml}_{\kappa} \mathrm{B} \alpha$ expressing line, $3 \mathrm{M}$, was able to translocate NF- $\kappa \mathrm{B}$ after $\mathrm{P} / \mathrm{I}$ treatment indicating that the decrease in $\mathrm{NF}-\kappa \mathrm{B}$ translocation requires expression of the transgene and is not just caused by the selection process.

\section{FasL expression is dependent on NF- $\kappa \mathrm{B}$ translocation}

The study of Yang and colleagues ${ }^{12}$ suggested to us that glucocorticoid mediated inhibition of FasL may involve inhibition of $\mathrm{NF}-\kappa \mathrm{B}$. In addition, cloning of FasL upstream sequence uncovered a putative NF- $k B$ site. ${ }^{68}$ To determine the effect of the inhibition of NF- $\kappa \mathrm{B}$ translocation on FasL expression, we first examined D011.10 cultures transfected with pCMV4-I $\mathrm{B}_{\alpha} \mathrm{S} 32 / 36 \mathrm{~A}$ using RT-PCR. Since this construct lacks an epitope tag, we were unable to follow transgene expression by Western blot. Figure 3A (lanes 1-7) displays a representative experiment. Cells were untreated or treated with $\mathrm{P} / \mathrm{I}$ for $2 \mathrm{~h}$ and RNA prepared by the acidified phenol method. ${ }^{69} \mathrm{RT}-\mathrm{PCR}$ was then performed using primers specific for FasL mRNA (Figure 3A, top) and for $\beta$ actin mRNA (Figure 3A, bottom) as described in Materials and Methods. As shown in Figure 3A, lane 2, untreated D011.10 cultures did not express detectable FasL transcripts. After P/I treatment however, a robust band was detected corresponding exactly to the size expected for FasL (compare Figure 3A, lane 3 with Figure 3B, lane 8). We obtained several pCMV4$1 \kappa \mathrm{B} \alpha \mathrm{S} 32 / 36 \mathrm{~A}$ transfected D011.10 lines in which FasL expression could no longer be induced by $P / /$ treatment (compare Figure 3A, lane 3 with lanes 6 and 7). In comparison, expression of the neomycin resistance gene had no effect on FasL expression (compare lane 3 with lanes 4 and 5). In a separate experiment (Figure 3A, lanes 8-12), another $\mathrm{pCMV} 4-\mathrm{I}_{\kappa} \mathrm{B} \alpha \mathrm{S} 32 / 36 \mathrm{~A}$ transfected D011.10 line, $\mathrm{I}_{\kappa} \mathrm{B} 2$, was found to express low levels of Fas $\mathrm{L}$ in response to $\mathrm{P} / \mathrm{I}$ 
treatment as compared to parental and Neo expressors (compare Figure 3A lanes 9-11). Once again, the $I_{\kappa} \mathrm{B} 4$ line was unable to express FasL mRNA (Figure 3A, lane 12). All cellular derived cDNAs amplified roughly equivalent amounts of the $300 \mathrm{bp} \beta$-actin fragment indicating that lack of amplified FasL is not due to RNA degradation (Figure $3 A$ and $B$, bottom panels). Interestingly, several weeks later, several of these pCMV4-I $\kappa \mathrm{B} \alpha \mathrm{S} 32 / 36 \mathrm{~A}$ transfected D011.10 lines regained their ability to generate FasL mRNA in response to $P / I$ treatment (data not shown), suggesting the possibility that the transgene was no longer expressing properly. This prompted us to generate new lines containing the mutant $\mathrm{I}_{\kappa} \mathrm{B} \alpha$ tagged with the FLAG epitope as described above and as shown in Figure 1. As shown in Figure 3B, expression of the FLAG tagged transgene in 2B4.11 $\mathrm{T}$ cell hybridomas (line 4P) resulted once again in the loss of FasL mRNA expression while expression of the neomycin resistance gene had no effect (Figure 3B, compare lane 3 with lanes 5 and 7). Because of the genetic instability of these $T$ cell hybridoma cultures, these lines were screened regularly by Western blot (Figure 1). Transgene expression was often lost within 1-3 months of culture. In order to control for potential changes in the expression level of the transgene, each treatment group was divided into equal aliquots and examined at several levels. Expression of FasL mRNA abundance was determined by RT-PCR as described above. Loss of expression of the $\mathrm{ml} \kappa \mathrm{B} \alpha$ transgene invariably resulted in reappearance of the FasL mRNA upon $\mathrm{P} / \mathrm{l}$ treatment further suggesting that FasL expression is specifically inhibited by the functional inhibition of NF- $\kappa$ B (data not shown).
The second matched aliquot of cells was analyzed for functional FasL protein. To this end, our variously treated 2B4.11 cultures (effector cells) were mixed with ${ }^{51} \mathrm{Cr}$ loaded L1210-Fas cells, which express high levels of Fas (target cells). Expression of functional FasL protein on the effector cell surface will cause target cell lysis and release of ${ }^{51} \mathrm{Cr}$ into the culture medium. All untreated 2B4.11 lines induced target cell lysis indistinguishable from the spontaneous lysis rates (Figure $3 \mathrm{C}$ ). Parental and neo over-expressors, when treated with $\mathrm{P} / \mathrm{I}$ and co-cultured with the target cells, induced significantly higher rates of lysis (averages of 56 and $70 \%$ respectively in the illustrated experiment). Lines expressing high levels of $\mathrm{ml} \kappa \mathrm{B} \alpha$ however, upon treatment with $\mathrm{P} / \mathrm{I}$, showed no significant increase in target cell lysis, indicating a lack of expression of functional FasL (Figure 3C). Consistent with the PCR data above, low $\mathrm{ml} \kappa \mathrm{B} \alpha$ expressing lines showed intermediate lysis of targets upon $P / I$ treatment, while loss of transgene expression correlated with significant levels of target cell lysis upon $\mathrm{P} / \mathrm{I}$ treatment (data not shown). We conclude from these experiments that these cells express functional FasL upon activation and that this expression requires the activation of NF- $\kappa \mathrm{B}$.

While this work was in progress, a report was published demonstrating that cell damaging agents such as teniposide and etoposide induce expression of FasL in Jurkat $T$ cell cultures through induction of NF- $\kappa \mathrm{B} .{ }^{70}$ They cloned the FasL promoter and identified an NF- $\kappa \mathrm{B}$ site approximately $1100 \mathrm{bp}$ upstream from the transcription start site. Mutation of this site blocked the ability of DNA damaging agents from inducing the promoter. This work demonstrated that
A

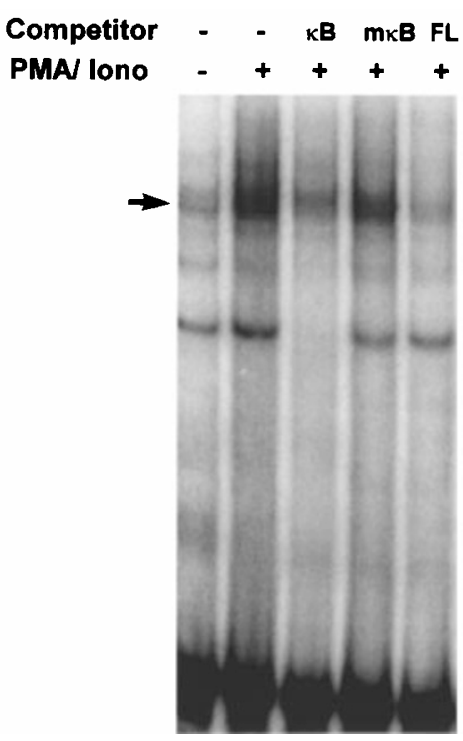

B

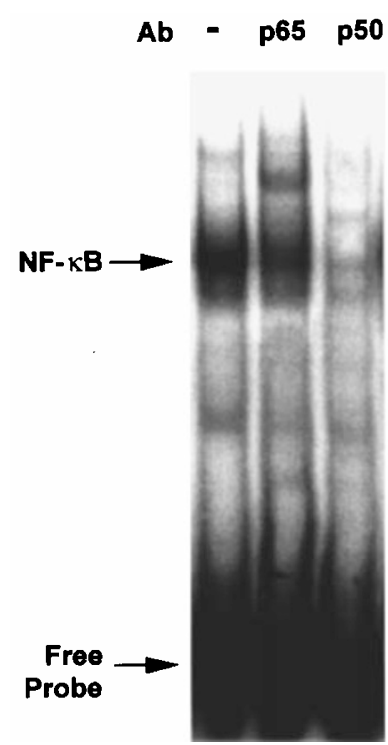

C

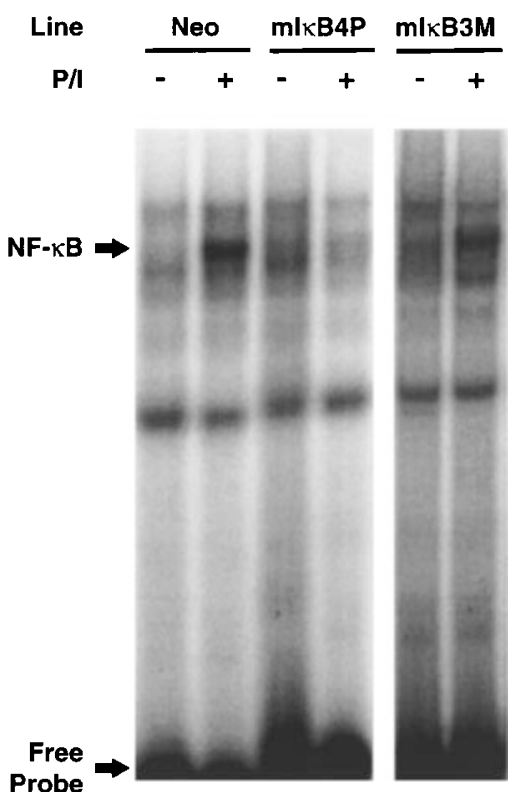

Figure 2 Analysis of NF- $\kappa$ B DNA binding in 2B4.11 parental and transfected lines. (A) Nuclear extracts from control and PMA plus ionomycin (PMA/iono) activated 2B4.11 parental cultures were incubated with a probe encoding the FasL promoter NF- $\kappa$ B site in the presence of various unlabeled DNA competitors. Results were examined by EMSA and visualized by Phosphor Imager. $\kappa \mathrm{B}$ : NF- $\kappa \mathrm{B}$ site from the $\mathrm{H} 2-\mathrm{K}^{\mathrm{b}} \mathrm{MHC}$ class I promoter, $\kappa \mathrm{m}$ : mutated $\kappa \mathrm{B}$ sequence, FL: FasL $\mathrm{NF}-\kappa \mathrm{B}$ site. The arrow marks the location of the NF- $\kappa \mathrm{B}$ complex. (B) Nuclear extract from a PMA/ionomycin activated $2 \mathrm{~B} 4.11$ culture was preincubated with antibodies specific for NF- $\kappa$ B relA (p65) or p50 subunits and analyzed as in (A). (C) A 2B4.11 neo expressor, line 4P, and line 3M were either untreated or activated with PMA/ionomycin $(\mathrm{P} / \mathrm{I})$ and nuclear extracts analyzed as in $(\mathbf{A})$ 
A

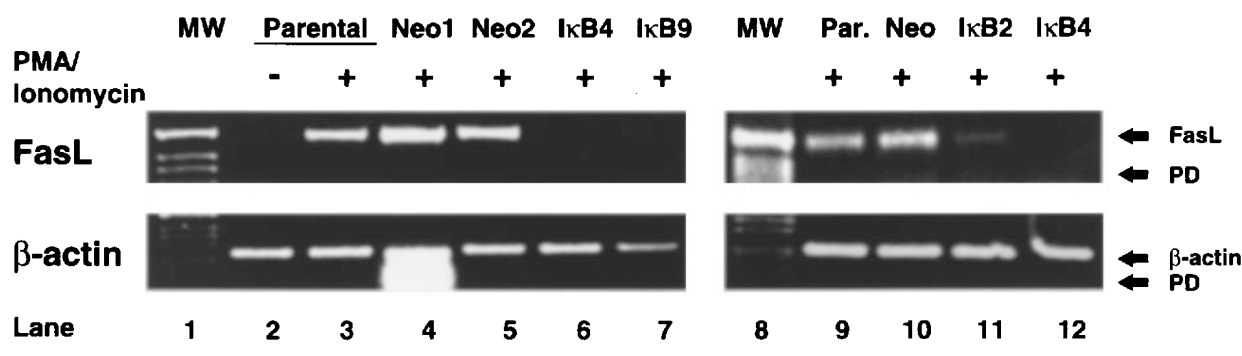

B

MW Parental Neo mlkB Control

PMA

lonomycin

FasL

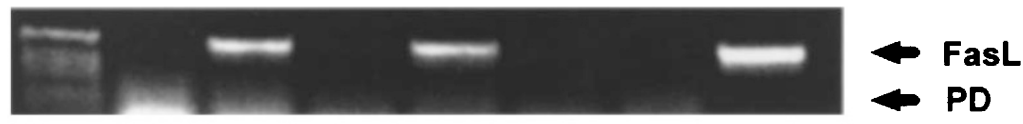

$\beta$-actin

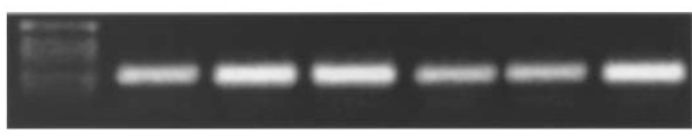

$\beta$-actin

Lane

123

45

67

8

C

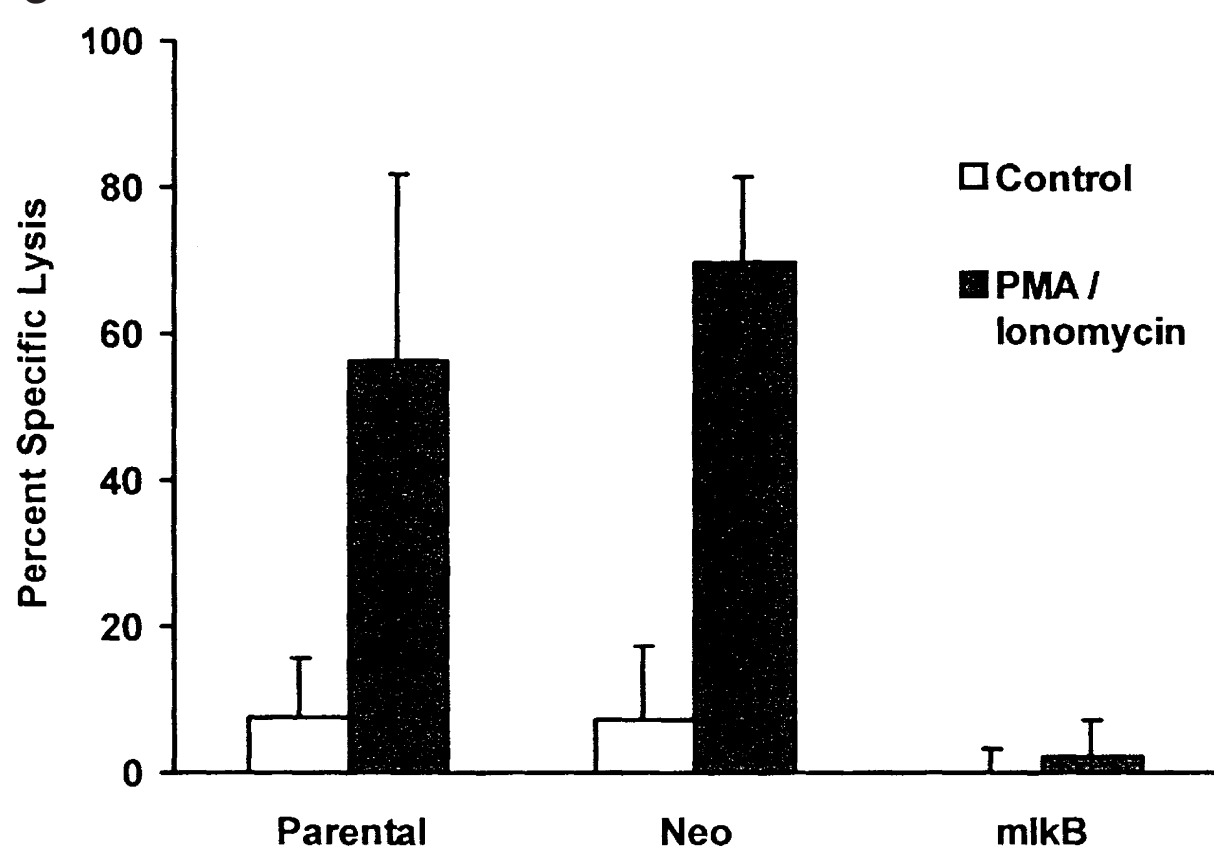

Figure 3 Analysis of FasL expression. (A) D011.10 parental, pCl-neo transfected lines (Neo1, Neo2), and pCMV4- $\left.\right|_{\kappa} \mathrm{B} \alpha \mathrm{S} 32 / 36 \mathrm{~A}$ transfected lines $\mathrm{I}_{\kappa} \mathrm{B} 2$, $\mathrm{I}_{\kappa} \mathrm{B} 4$, and $I_{\kappa} \mathrm{B} 9$ were untreated or treated for $2 \mathrm{~h}$ with PMA/ionomycin. RNA was prepared and analyzed by RT-PCR for FasL (top panel) and $\beta$-actin (bottom panel) as described in Materials and Methods. MW: $1 \mathrm{~kb}$ ladder (Gibco). PD: primer dimer. (B) $2 \mathrm{~B} 4.11$ parental, Neo1 (Neo), and 4P (mlkB) lines were treated and mRNA prepared and analyzed as in (A) Control: RT-PCR from a FasL cDNA plasmid, PD: Primer dimers. (C) PMA/lonomycin treated and untreated 2B4.11 parental, $\mathrm{Neo}-1$, and $4 \mathrm{P}(\mathrm{ml} \kappa \mathrm{B})$ lines were co-cultured with $\mathrm{L} 1210$ Fas expressing target cells pre-loaded with ${ }^{51} \mathrm{Cr}$. Specific lysis was calculated as per methods and materials. Open bars: Untreated control, Filled bars: PMA/ionomycin treated. Data represents three independent determinations. Error bars denote standard deviation 
$\mathrm{NF}-\kappa \mathrm{B}$ acts directly to induce transcription of FasL when activated by DNA damaging agents. Our work confirms this observation and demonstrates that $\mathrm{T}$ cell activator mediated induction of FasL is also dependent on the nuclear translocation of NF- $\kappa \mathrm{B}$.

\section{Inhibition of NF- $\kappa$ B in T cell hybridomas has both proapoptotic and antiapoptotic effects depending on cellular context}

Engagement of Fas has been shown to play a major role in the induction of AICD. ${ }^{16-18}$ To determine the effect of the inhibition of NF- $\kappa B$ activation and FasL expression on AICD, 2B4.11 cultures were treated with either P/I or with anti-CD3 for $24 \mathrm{~h}$ and viability determined by trypan blue exclusion. As shown in Figure $4 \mathrm{~A}$, we observed $87 \%( \pm 1 \%)$ killing of the
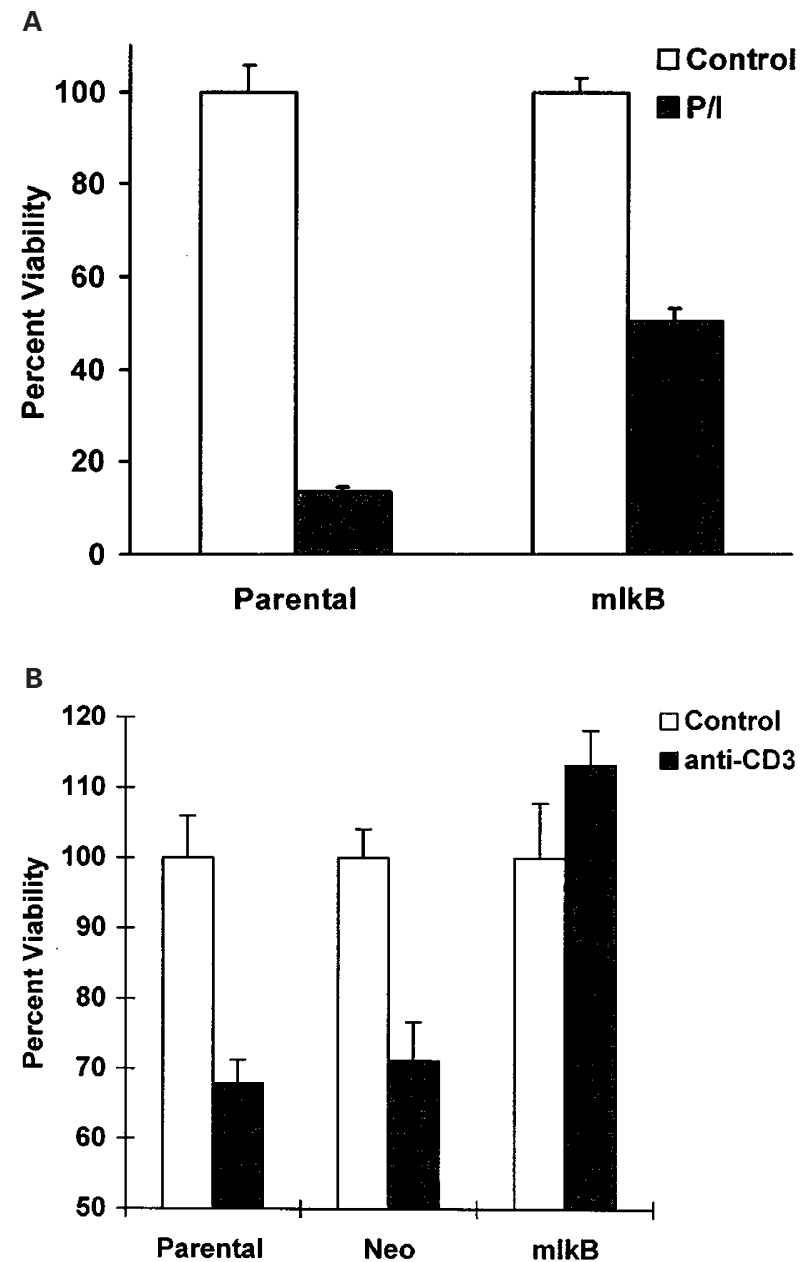

Figure 4 Effect of NF- $\kappa$ B inhibition on cell viability after activation. (A) 2B4.11 parental and 4P $\left(\mathrm{ml}_{\kappa} \mathrm{B}\right)$ lines were untreated or treated for $24 \mathrm{~h}$ with $\mathrm{PMA} /$ ionomycin. Cell viability was assayed by trypan blue exclusion. Data is representative of three independent experiments. Error bars denote standard deviation. (B) 2B4.11 parental, Neo-1 ( $\mathrm{Neo})$, or $4 \mathrm{P}\left(\mathrm{ml}_{\kappa} \mathrm{B}\right)$ lines were treated with anti-CD3 for $24 \mathrm{~h}$ as described in Materials and Methods and cell viability measured by trypan blue exclusion. Data is representative of four independent experiments. Error bars denote standard deviation parental 2B4.11 cultures after $24 \mathrm{~h}$ treatment with $\mathrm{P} / \mathrm{l}$ as compared to matched untreated cultures. In comparison, the 2B4.11 4P line showed 49\% ( $\pm 3 \%)$ killing upon similar treatment. Thus the $\mathrm{ml} \kappa \mathrm{B} \alpha$ transgene seems to function to inhibit cell death, suggesting that NF- $\kappa \mathrm{B}$ activity is necessary for efficient killing to occur. $\mathrm{P} / \mathrm{I}$ treatment is a powerful $\mathrm{T}$ cell activator which functions downstream from the TCR. In order to determine the effect of cell death mediated solely by activation of the TCR, 2B4.11 cultures were treated with antiCD3 as described in Materials and Methods. As shown in Figure 4B, treatment of parental cultures resulted in a $32 \%$ $( \pm 4 \%)$ loss in viability after $24 \mathrm{~h}$ while similarly treated Neo expressors experiences a $29 \%( \pm 6 \%)$ loss in viability. In comparison, the 2B4.11 4P line experienced a 13\% $( \pm 5 \%)$ increase in viability. These data suggest that loss of viability, when mediated specifically through activation of the TCR, is completely blocked by overexpression of the $\mathrm{ml} \kappa \mathrm{B} \alpha$ transgene.

Our viability assay cannot distinguish between increased cell death versus decreased proliferation. In order to determine if this increase in cell survival was due to a partial or complete inhibition of apoptosis, cells were treated with either PMA, ionomycin, or $\mathrm{P} / \mathrm{I}$ for $24 \mathrm{~h}$ as above and then assayed for cell death visually by the ethidium bromide/acridine orange technique as described in Methods and Materials. ${ }^{71}$ As shown in Figure $5 \mathrm{~A}$, neither PMA or ionomycin alone induced appreciable levels of apoptosis in parental 2B4.11 cells. Treatment of parental 2B4.11 cells with $\mathrm{P} / \mathrm{I}$ however resulted in approximately $25 \%$ of the population clearly showing an apoptotic morphology while in the 2B4.11 4P line, apoptosis was indistinguishable from background. These data suggest that inhibition of NF- $\kappa \mathrm{B}$ has a profound effect on the ability of $\mathrm{T}$ cell hybridomas to undergo apoptosis in response to direct activation of the TCR or to activation of downstream TCR signaling components.

If expression of $\mathrm{NF}-\kappa \mathrm{B}$ plays an important role in induction of apoptosis mediated by $\mathrm{P} / \mathrm{I}$ treatment then we would expect a rough correlation between expression of the $\mathrm{ml} \kappa \mathrm{B} \alpha$ transgene and protection from induction of $\mathrm{P} / \mathrm{l}$ mediated apoptosis. To test this hypothesis we measured apoptosis in a variety of D011.10 and 2B4.11 lines expressing variable amounts of the $\mathrm{ml}_{\kappa} \mathrm{B} \alpha$ transgene. As shown in Figure 5B (left) we measured the induction of apoptosis in the D011.10 $\mathrm{l} \kappa \mathrm{B} 2$ line as compared to a Neo expressor. Since this line was created with pCMV4$I_{\kappa} \mathrm{B} \alpha \mathrm{S} 32 / 36 \mathrm{~A}$, we were unable to directly measure the expression of the transgene. Nevertheless, as shown in Figure $3 \mathrm{~A}$, lane 11 , the $\mid \kappa \mathrm{B} 2$ expresses significantly less FasL mRNA in response to $\mathrm{P} / \mathrm{l}$ stimulation than the parental or Neo expressing cells. We found that this loss in FasL expression correlated with a partial protection from $\mathrm{P} / \mathrm{I}$ induced apoptosis as compared to the Neo expressor. We then measured the induction of apoptosis in a variety of 2B4.11 lines expressing varying amounts of the FLAG epitope tagged $\mathrm{ml}_{\kappa} \mathrm{B} \alpha$ transgene as shown in Figure 1. Line $3 \mathrm{P}$ is a moderate expressor of the $\mathrm{ml} \kappa \mathrm{B} \alpha$ transgene and as shown in Figure 5 , is partially protected from $P / l$ mediated apoptosis. In comparison, lines $3 \mathrm{M}$ and $4 \mathrm{M}$ have barely detectable levels of transgene expression and are 
A

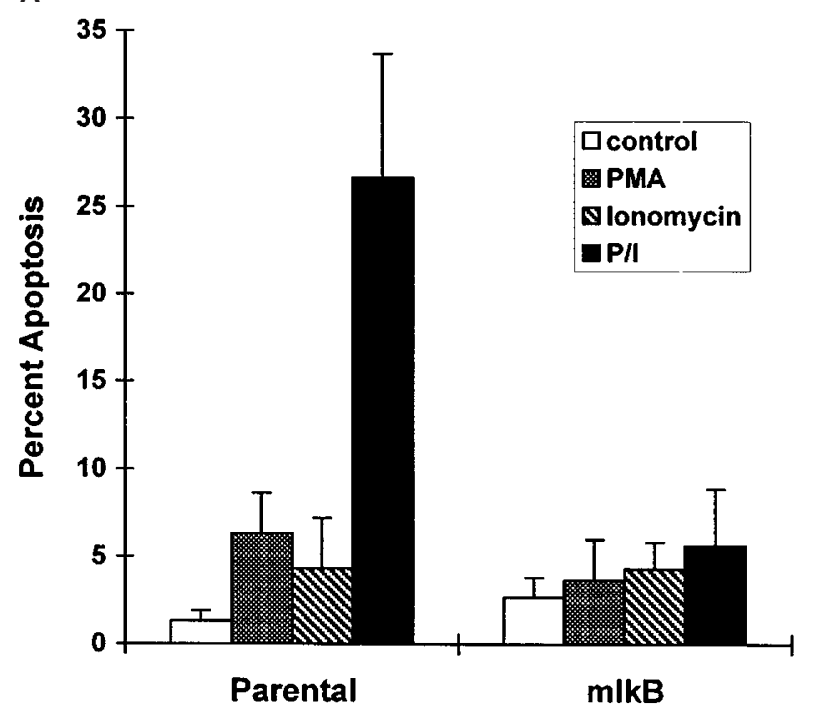

B

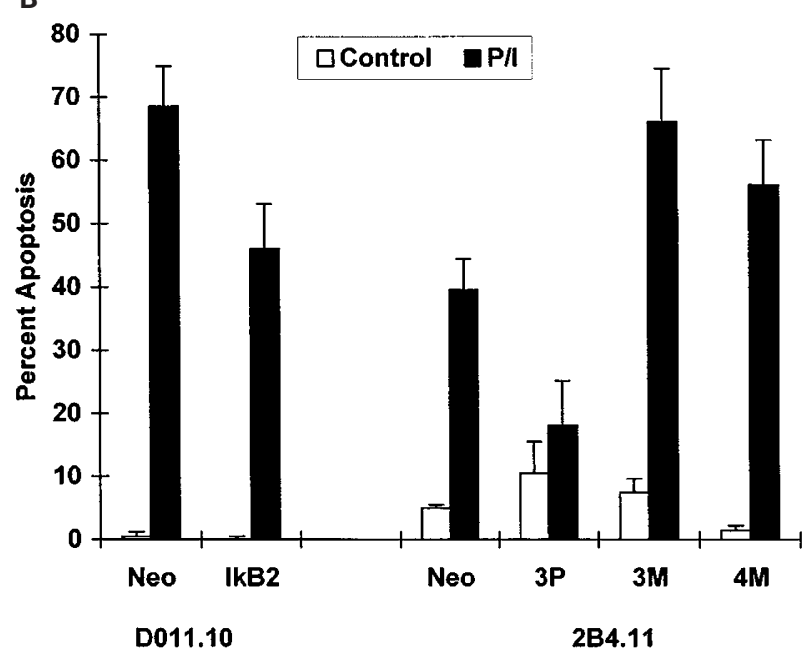

Figure 5 Effect of NF- $k$ B inhibition on apoptosis after activation. Apoptosis was morphologically determined using the ethidium bromide/acridine orange technique. ${ }^{71}$ Per cent apoptosis was calculated as (apoptotic population counted/total population counted) as described in Methods and Materials. Error bars denote standard deviation. (A) 2B4.11 parental and 4P lines were either left untreated or treated $24 \mathrm{~h}$ with PMA alone, ionomycin alone, or PMA plus ionomycin (P/l) as described in Materials and Methods. Data represents three independent experiments. Error bars denote standard deviation. (B) D011.10 lines (left) or 2B4.11 lines (right), transfected with either $\mathrm{pCl}-\mathrm{NeO}$ (Neo), pCl-Neo plus pCMV4-I $k \mathrm{~B} \alpha \mathrm{S} 32 / 36 \mathrm{~A}$ ( $\mathrm{I}_{\kappa} \mathrm{B} 2$ ), or $\mathrm{pCl}-\mathrm{Neo}$ plus $\mathrm{pCMV} 4$ $\mathrm{FLAG}-\mathrm{I}_{\kappa} \mathrm{B} \alpha \mathrm{S} 32 / 36 \mathrm{~A}(3 \mathrm{P}, 3 \mathrm{M}$, and $4 \mathrm{M})$ were treated $24 \mathrm{~h}$ with $\mathrm{P} / \mathrm{l}$ and apoptosis determined as in $(\mathbf{A})$

completely unprotected from the effects of $\mathrm{P} / \mathrm{l}$ treatment. These data suggest that protection from apoptosis correlates directly with varying levels of FasL expression and inversely with expression of the $\mathrm{ml}_{\kappa} \mathrm{B} \alpha$ transgene.

Given our earlier work demonstrating the inhibition of $\mathrm{NF}-\kappa \mathrm{B}$ by glucocorticoids ${ }^{63,65}$ as well as our current data linking NF- $\kappa$ B to FasL expression, we hypothesized that blockade of $\mathrm{NF}-\kappa \mathrm{B}$ might result in an increased sensitivity

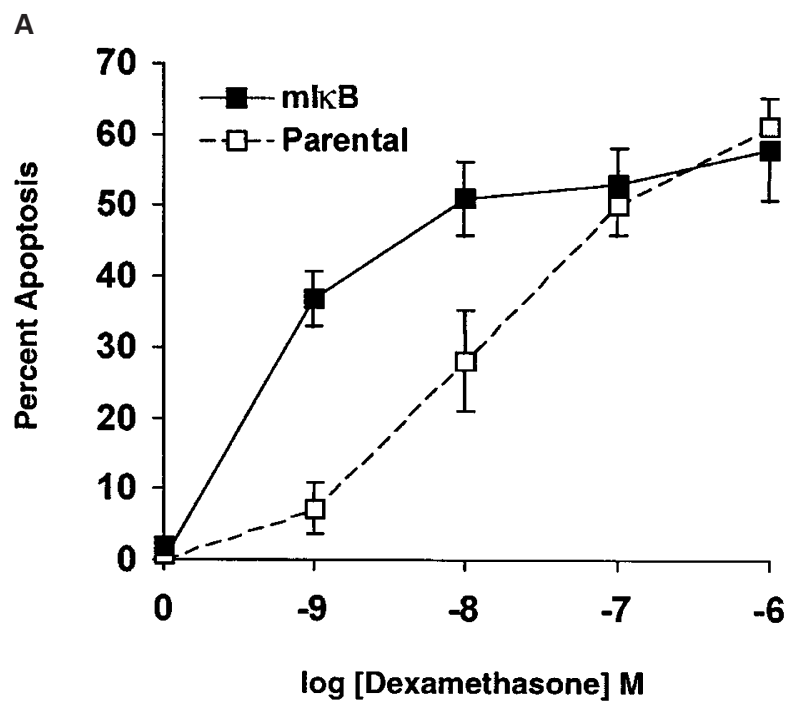

B

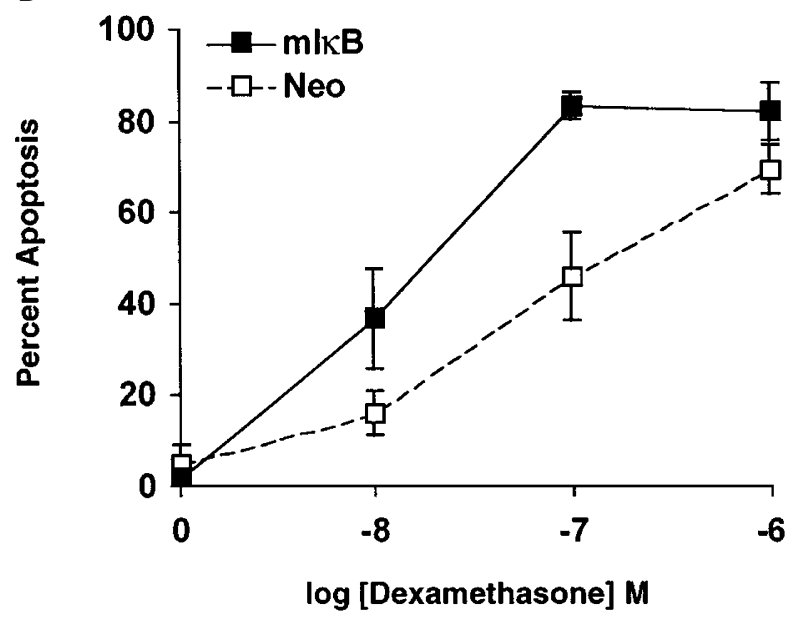

Figure 6 Effect of NF- $\kappa \mathrm{B}$ inhibition on dexamethasone induced apoptosis. Apoptosis was determined as described in Figure 5. Data represents three independent determinations. Error bars denote standard deviation. (A) D011.10 parental and $\mathrm{I}_{\kappa} \mathrm{B} 9(\mathrm{ml} \kappa \mathrm{B})$ lines were treated $24 \mathrm{~h}$ with varying concentrations of dexamethasone as shown. Filled square/solid line: $I_{\kappa} \mathrm{B} 9$, Open square/dashed line: parental D011.10 line. (B) 2B4.11 Neo-1 (Neo) and $4 \mathrm{P}(\mathrm{ml} \kappa \mathrm{B})$ lines were treated for 24 with varying concentrations of dexamethasone as shown. Filled square/solid line: 2B4.11 4P line $(\mathrm{ml} \kappa \mathrm{B})$, Open square/dashed line: 2B4.11 Neo-1 line (Neo)

to glucocorticoid mediated apoptosis. In order to test this possibility, we incubated either the parental D011.10 and the $1 \kappa \mathrm{B} 9$ lines (Figure $6 \mathrm{~A}$ ) or the 2B4.11 Neo expressors and the 2B4.11 4P line (Figure 6B) with varying concentrations of dexamethasone (DEX) for $24 \mathrm{~h}$. Apoptosis was again measured by the acridine orange/ethidium bromide technique. As expected, increasing concentrations of DEX resulted in increasing levels of apoptosis both for parental D011.10 and for 2B4.11 Neo expressing cultures in a similar fashion. Expression of the $\mathrm{ml}_{\kappa} \mathrm{B}$ transgene in the D011.10 $\mathrm{I} \kappa \mathrm{B} 9$ line resulted in approximately a tenfold increase in sensitivity to DEX mediated apoptosis (Figure 
6A). A similar increase in sensitivity was observed in our 2B4.11 4P expressing line (Figure 6B). Thus, while expression of the $\mathrm{ml} \kappa \mathrm{B} \alpha$ transgene protects $\mathrm{T}$ cell hybridomas from $\mathrm{P} / \mathrm{l}$ mediated apoptosis, in the context of glucocorticoid treatment, inhibition of NF- $\kappa \mathrm{B}$ activity results in a significant increase in apoptosis in two different $\mathrm{T}$ cell lines.

\section{NF- $\kappa$ B is not required for the mutual inhibition mediated by P/I and glucocorticoids}

As demonstrated in earlier studies, exposure to $T$ cell activators in the presence of glucocorticoids induces a mutual inhibition of the two apoptotic signals. ${ }^{8,9}$ We next wanted to determine if inhibition of NF- $\kappa \mathrm{B}$ had any effect on this phenomena. Parental 2B4.11, Neo-3, 3P, and 5P lines were incubated with varying amounts of DEX for $24 \mathrm{~h}$ in the absence or presence of $\mathrm{P} / \mathrm{I}$. Apoptosis was measured by the acridine orange/ethidium bromide technique. At the maximal dose of glucocorticoid, we counted approximately 60 to $70 \%$ of the cells as apoptotic (Figure 7). P/l treatment alone in this experiment produced $27 \%( \pm 5.7 \%)$ apoptosis in our neo-3 line and $5 \%( \pm 1.4 \%)$ in our $3 \mathrm{P}$ line (data not shown). While either DEX or $\mathrm{P} / \mathrm{l}$ treatment alone induced apoptosis, when combined, apoptosis levels were indistinguishable from background (Figure 7), consistent with the observations of others. ${ }^{8,9}$ Inhibition of NF- $\kappa$ B activity had a small effect, if any, on this result. Thus while inhibition of $\mathrm{NF}-\kappa \mathrm{B}$ has opposite effects on these two apoptosis pathways which are mutually inhibitory, surprisingly, NF- $\kappa \mathrm{B}$ does not play a role in the mutual inhibition that occurs between these two pathways.

\section{Discussion}

A central paradox in thymic selection is that one signal can mediate survival or the induction of apoptosis depending on

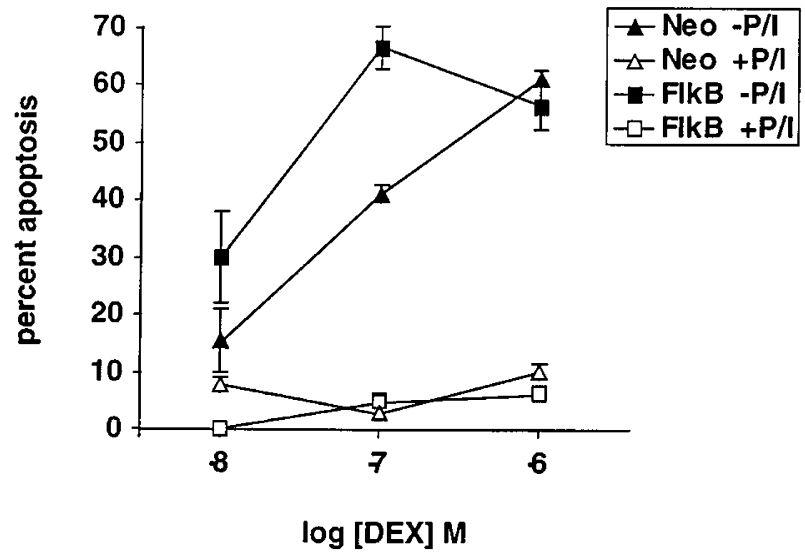

Figure 7 Effect of NF- $k$ B inhibition on the mutual inhibition between $P / I$ and dexamethasone induced apoptosis. The 2B4.11 Neo-3 line (triangles) and 2B4.11 3P line (squares) were treated with varying concentrations of DEX as shown in the absence (filled symbols) or presence (open symbols) of PMA/ ionomycin for $24 \mathrm{~h}$. Apoptosis was determined as described in Figure 5. Data represent three separate determinations and is representative of experiments with other $\mathrm{ml} \kappa \mathrm{B} \alpha$ expressing lines. Error bars denote standard deviation the strength of the signal and the differentiation state of the $\mathrm{T}$ cell. Our interest in this problem arose through several linked observations. In our studies of NF- $\kappa \mathrm{B}$, we discovered an interaction between the glucocorticoid receptor and NF$\kappa \mathrm{B}$ resulting in the mutual inhibition of these two transcription factors which functioned at several levels including physical interaction and induction of $\mathrm{I}_{\kappa} \mathrm{B} \alpha^{63,65}$ Others have more recently shown that NF- $\kappa \mathrm{B}$ and GR also compete for the co-activator p300/CBP. ${ }^{67}$ During this time, several reports demonstrated that glucocorticoids were produced in the thymic epithelium and that blockade of either glucocorticoid production or blockade of glucocorticoid receptor synthesis resulted in increased thymocyte survival during positive selection. ${ }^{10,11}$ A previous report from the same group had demonstrated that $\mathrm{T}$ cell activation could block glucocorticoid mediated apoptosis. ${ }^{8}$ Interestingly, glucocorticoid treatment was found to block anti-CD3 mediated induction of FasL. ${ }^{12}$

Given the recent observations that $\mathrm{NF}-\kappa \mathrm{B}$ can play a role as either antiapoptotic or proapoptotic regulator, our hypothesis, derived from these observations, was that glucocorticoid interactions with $\mathrm{NF}-\kappa \mathrm{B}$ might play a role in thymic selection. We chose to address this hypothesis by inhibiting NF- $\kappa \mathrm{B}$ activity using the dominant negative mutant $\mathrm{I} \kappa \mathrm{B} \alpha$. The detailed apoptosis studies of Ashwell and others made the $\mathrm{T}$ cell hybridomas 2B4.11 and D011.10 attractive model systems for this study. In our initial experiments we chose to look at the effects of inhibition of $\mathrm{NF}-\kappa \mathrm{B}$ on both activation induced apoptosis (AICD) and glucocorticoid induced apoptosis. Others have shown in this hybridoma model that AICD is mediated by the upregulation of FasL and its engagement with Fas. ${ }^{6,12}$ We found that inhibition of $\mathrm{NF}-\kappa \mathrm{B}$ results in a loss of the induction of FasL mRNA in both 2B4.11 and DO11.10 (Figure 3), as well as a decrease in AICD mediated apoptosis (Figure 4 and 5). Our method of measuring apoptosis is conservative in that at the time the counts were performed, a number of cells may have already been eliminated and thus would not be counted as apoptotic. A useful experiment would be to reintroduce FasL expression to NF- $\kappa \mathrm{B}$ inhibited cells and show that protection from AICD is blocked. We have attempted to perform this experiment through transient transfection techniques using our $\mathrm{T}$ cell hybridomas but low transfection efficiencies have stymied this attempt. In addition, while AICD was significantly decreased by inhibition of $N F-\kappa B$ it was never totally eradicated (Figure 5A and data not shown). This would suggest that a Fas-independent apoptotic pathway may also be activated in these cells however further work will be necessary to define these points.

While our studies were in progress several reports were published indicating that $\mathrm{NF}-\kappa \mathrm{B}$ was an important regulator of FasL. The HTLV-1 Tax protein induces the expression of FasL and promotes apoptosis in Jurkat cells. $^{72}$ Tax is known to activate NF- $\kappa \mathrm{B}$ as well as the CREB/ATF transcription factor family through different domains. Interestingly, mutants of Tax which are selectively deficient in the activation of either $\mathrm{NF}-\kappa \mathrm{B}$ or of CREB/ATF are incapable of inducing the FasL. A 
combination of these mutants however restores the ability to induce FasL and mediate apoptosis. This strongly suggests that $\mathrm{NF}-\kappa \mathrm{B}$ and $\mathrm{CREB} / \mathrm{ATF}$ activities are necessary for the induction of FasL. Others have linked $\mathrm{NF}-\kappa \mathrm{B}$ activity with the induction of FasL through modulation of proteosome function using the bacterial metabolite, lactacystin. ${ }^{73}$ They found that agents which inhibited NF- $\kappa$ B activation also inhibited induction of FasL. More recently, a study of the DNA damaging agents, etoposide and teniposide, demonstrated that in Jurkat $T$ cells, apoptosis was mediated through the induction of FasL and that NF- $\kappa \mathrm{B}$ and $\mathrm{AP}-1$ activities were essential for this induction. ${ }^{70}$ The authors cloned the FasL promoter, identified an $\mathrm{NF}-\kappa \mathrm{B}$ site between 0.9 and $1.2 \mathrm{~kb}$ upstream from the transcription start site, and demonstrated that mutation of that site resulted in a loss of etoposide mediated induction. This report thus supplies a mechanistic framework for our results, indicating that $\mathrm{NF}-\kappa \mathrm{B}$ is directly required for activation of FasL transcription. Our work extends the results of Kasibhatla et al. by demonstrating that $\mathrm{T}$ cell activation signals work in a manner similar to DNA damaging agents in respect to FasL induction. This is interesting in that an NFAT site, located approximately $200 \mathrm{bp}$ upstream from the transcription start site, was also identified as an important regulator of the FasL promoter. ${ }^{74}$ Unlike etoposide, PMA/ ionomycin treatment activates NFAT. Our results suggest that NFAT activation is not sufficient to activate the FasL promoter in the absence of $\mathrm{NF}-\kappa \mathrm{B}$. Interestingly we have generated preliminary data demonstrating that both NF- $\kappa \mathrm{B}$ and SP-1 are capable of binding to the putative NFAT site in EMSA assays (Cano and Scheinman, unpublished observations). The function of the NFAT site in the regulation of FasL promoter activity may be more complex than originally suspected. A second level of complexity comes from the study of transgenic mice in which the expression of the $\mathrm{I} \kappa \mathrm{B} \alpha$ mutant has been directed to thymocytes. FasL expression was detected in peripheral $\mathrm{T}$ cells derived from these animals. ${ }^{61}$ This would suggest that NF- $\kappa \mathrm{B}$ may not be required for FasL expression in all $T$ cell contexts however the extent to which the mutant $\mathrm{I} \kappa \mathrm{B} \alpha$ inhibits NF- $\kappa \mathrm{B}$ in mature $\mathrm{T}$ cells in this transgenic mouse has not been fully explored. Constitutive expression of FasL, as seen in Sertoli cells, would not be predicted to require NF- $\kappa \mathrm{B}$ activation.

It is clear that there is no general role for $\mathrm{NF}-\kappa \mathrm{B}$ in the regulation of apoptosis but rather, NF- $\kappa$ B functions as a complex and cell specific regulator of apoptosis. In a study of Fas resistant T24 human bladder carcinoma cells, it was observed that ligation of Fas resulted in the activation of $\mathrm{NF}-\kappa \mathrm{B}$ while no such activation was observed in Jurkat $\mathrm{T}$ cells. ${ }^{75}$ In a separate study, ligation of Fas in Jurkat $T$ cells was shown to inhibit NF- $\kappa B$ activity, via a caspase-3-related protease mediated cleavage of relA and $\mathrm{p} 50$ thus inhibiting $\mathrm{NF}-\kappa \mathrm{B}$ activity early in the apoptotic process. ${ }^{76}$ Another group has also recently reported that $\mathrm{c}$ - $\mathrm{Rel}$ expression prevents both TNF $\alpha$ and FasL mediated apoptosis in transformed lymphoid cells. ${ }^{77}$ It is important to note in each of these cases that apoptosis, when mediated by the ligation of a death receptor, requires the interaction of an effector cell with a target cell. These data would suggests that the proapoptotic function of $\mathrm{NF}-\kappa \mathrm{B}$ is limited to a point upstream of Fas ligation, within the effector cell, and that $N F-\kappa B$ activity may interfere with later stages of the apoptotic process within the target cell, perhaps due to the ability of NF- $\kappa \mathrm{B}$ to induce antiapoptotic genes such as clAP and TRAFs. ${ }^{43}$ In this regard, it will be interesting to see whether $\mathrm{NF}-\kappa \mathrm{B}$ functions in a similar fashion as a proapoptotic regulator in the CNS.

In the present study, we demonstrate, for the first time, that DEX mediated apoptosis is sensitive to the state of NF$\kappa \mathrm{B}$ activity. Inhibition of $\mathrm{NF}-\kappa \mathrm{B}$ results in a tenfold increase in the sensitivity of these cells to DEX (Figure 6 and 7). Previously, we have shown that GR and NF- $\kappa$ B interact to mutually inhibit each other. Thus one interpretation of this result in that by inhibiting NF- $\kappa \mathrm{B}$ we have removed an inhibitor of GR function, allowing more GR to be available to induce apoptosis. We do not favor this hypothesis however as NF- $\kappa$ B must be induced to function, suggesting that release from $\mathrm{I}_{\kappa} \mathrm{B} \alpha$ is a prerequisite for interaction with GR. Indeed, we can only detect low levels of NF- $\kappa$ B DNA binding activity in nuclear extracts derived from uninduced $T$ cell hybridomas (Figure 2 and data not shown). In addition, we have found that an excess of NF- $\kappa$ B must be present to physically inhibit GR. ${ }^{63} A$ second interpretation of Figure 6 is that low levels of NF- $\kappa \mathrm{B}$ activity, found in uninduced $\mathrm{T}$ cells, activate the expression of one or more genes which function to inhibit DEX mediated apoptosis. Indeed as mentioned above, several apoptosis inhibitors have recently been reported to be under NF- $\kappa \mathrm{B}$ control and play an important role in protecting from $\mathrm{TNF} \alpha$ induced apoptosis. ${ }^{43,44,78}$ It will be interesting to see what role these genes might play in the regulation of glucocorticoid mediated apoptosis.

These results supply a physiological interpretation to our previous discovery that $\mathrm{GR}$ and $\mathrm{NF}-\kappa \mathrm{B}$ are mutually inhibitory and demonstrates a potential physiological role for $\mathrm{NF}-\kappa \mathrm{B}$ as a regulator of apoptosis in the immune system. We hypothesize that during thymic selection, NF$\kappa \mathrm{B}$ protection from glucocorticoid mediated apoptosis may represent a mechanism by which thymocytes survive positive selection. In order to induce apoptosis, GR must induce genes (such as $\mid \kappa \mathrm{B} \alpha$ ) to block apoptosis inhibitors as well as to induce genes to promote apoptosis itself. After differentiation is completed, and the mature $T$ cell is exported to the periphery, the role of NF- $\kappa \mathrm{B}$ then changes to promote the linkage of $T$ cell activation with eventual deletion through induction of proapoptotic molecules such as FasL. Most likely, other proapoptotic genes will be identified as NF- $\kappa$ B responsive in addition to FasL. Given that different forms of $\mathrm{NF}-\kappa \mathrm{B}$ are expressed at different points in $\mathrm{T}$ cell differentiation, it is intriguing to speculate that different forms of $\mathrm{NF}-\kappa \mathrm{B}$ may responsible for antiapoptotic and proapoptotic functions. As the mutant $I_{\kappa} \mathrm{B} \alpha$ inhibits all forms of $\mathrm{NF}-\kappa \mathrm{B}$, we were unable to address this issue in the present study. Further experiments will need to be performed in primary $T$ cells to identify which forms of $\mathrm{NF}-\kappa \mathrm{B}$ are responsible for these functions. 


\section{Materials and Methods}

\section{Cell culture}

D011.10 and 2B4.11 T cell hybridoma cultures were maintained in Dulbecco's Minimal Essential Media (DMEM; Gibco BRL) supplemented with 10\% FBS (Gemini Bio-Products) and PenicillinStreptomycin (50 units $/ \mathrm{ml}$ and $50 \mathrm{mg} / \mathrm{ml}$ respectively; Gibco BRL). $T$ cell hybridomas were kept at a concentration of 500000 cells $/ \mathrm{ml}$ or less. Stably transfected cells were further supplemented with $450 \mu \mathrm{g} / \mathrm{ml}$ of G418 Sulfate (Gemini Bio-Products) to select for transgene expression. Cells were maintained at $37^{\circ} \mathrm{C}$ and $5 \% \mathrm{CO}_{2}$. Cells were activated either by treatment with $5 \mathrm{ng} / \mathrm{ml}$ PMA and $500 \mathrm{ng} / \mathrm{ml}$ lonomycin (Sigma) or by treatment with anti-CD3 for varying periods of time. For anti-CD3 treatment, 96-well plates were coated with $100 \mu \mathrm{l} 5 \mu \mathrm{g} / \mathrm{ml}$ anti-CD3 (in PBS pH 9.0) overnight and washed with PBS (pH 7.0) before use.

\section{Transfection of cell lines}

D011.10 and 2B4.11 T cell hybridomas were stably transfected by electroporation. An aliquot of $2 \times 10^{6}$ cells were suspended in $500 \mu \mathrm{l}$ of RPMI 1640 media (Gibco BRL) supplemented with MEM NonEssential Amino Acids (Gibco BRL) and $1 \mathrm{mM}$ MEM Sodium Pyruvate (Gibco BRL). Using $0.4 \mathrm{~cm}$ electroporation cuvettes (Invitrogen) samples were electroporated at a capacitance of $960 \mu \mathrm{F}$ and 250 volts with $5 \mu \mathrm{g}$ of $\mathrm{pCl}$-neo (Promega) in the presence or absence of either $20 \mu \mathrm{g}$ of $\mathrm{pCMV} 4-\mathrm{I}_{\kappa} \mathrm{B} \alpha \mathrm{S} 32 / 36 \mathrm{~A}$ or $20 \mu \mathrm{g}$ of pCMV4-FLAG$I_{\kappa} \mathrm{B} \alpha \mathrm{S} 32 / 36 \mathrm{~A}$ (gifts of D. Ballard, Vanderbilt University). Cells were then removed and placed into $5 \mathrm{ml}$ of supplemented DMEM (as above) for $72 \mathrm{~h}$ then fed with G418 supplemented DMEM (as above) for further culture. After several days clones were isolated by dilution of the cells and plating into 96 well plates, then visually scanning for wells that contained single cells which were then cultured. Individual colonies were grown and frozen in aliquots before use.

\section{Electrophoretic mobility shift assays (EMSA)}

Extracts for EMSA were prepared from $10^{7}$ cells. T cell hybridomas were initially lysed by dounce homogenization in buffer A (10 mM Tris [pH 7.9], $0.75 \mathrm{mM}$ spermine, $0.15 \mathrm{mM}$ spermidine, $0.1 \mathrm{mM}$ EDTA, $0.1 \mathrm{mM}$ EGTA, $1 \mathrm{mM}$ DTT, $10 \mathrm{mM} \mathrm{KCl}$ ) and protease inhibitors (100 mg/ml PMSF, $100 \mu \mathrm{M}$ leupeptin, $10 \mu \mathrm{M}$ pepstatin A). The lysed cells were spun down $\left(12000 \times \mathrm{g}, 10 \mathrm{~min}, 4^{\circ} \mathrm{C}\right)$ and the supernatant removed. The nuclear pellet was quickly washed in $1 \mathrm{ml}$ buffer $A$ to remove residual cytoplasmic extract, spun $3 \mathrm{~min}$ as above, and then resuspended in $50 \mu \mathrm{l}$ buffer $\mathrm{C}(20 \mathrm{mM}$ Tris [pH 7.9], $0.75 \mathrm{mM}$ spermine, $0.15 \mathrm{mM}$ spermidine, $0.2 \mathrm{mM}$ EDTA, $2 \mathrm{mM}$ EGTA, $2 \mathrm{mM}$ DTT, $20 \%$ glycerol) plus protease inhibitors. The volume was measured and $\mathrm{NaCl}$ added to a final concentration of $0.4 \mathrm{M}$ while mixing. The nuclei were extracted on ice for $15 \mathrm{~min}$ with occasional mixing. The nuclei were then pelleted $\left(13000 \times g, 10 \mathrm{~min}, 4^{\circ} \mathrm{C}\right)$ and the supernatant was removed as nuclear extract. Nuclear and cytoplasmic extracts were aliquoted and quick frozen using dry ice/ethanol bath. Protein concentrations were measured by method of Bradford with BioRad dye reagent used according to the manufacturer's instructions. ${ }^{79}$

DNA binding reactions were performed incubating $2-5 \mu \mathrm{g}$ of nuclear extract with $0.5 \mu \mathrm{g}$ poly $(\mathrm{dl}-\mathrm{dC})$ in binding buffer $(5 \mathrm{mM}$ Tris [pH 7.0], $50 \%$ glycerol, $0.5 \mathrm{mM}$ DTT, $0.25 \mathrm{mM}$ EDTA) for $10 \mathrm{~min}$ at room temperature. Approximately 10000 c.p.m. of ${ }^{32} \mathrm{P}$-labeled DNA probe was then added and allowed to bind for $30 \mathrm{~min}$. The reaction was then loaded onto a $5 \%$ native acrylamide TGE $(25 \mathrm{mM}$ Tris, $190 \mathrm{mM}$ glycine, $1 \mathrm{mM}$ EDTA) gel. After gel electrophoresis, the gels were dried and data visualized by Phosphor Imager.
DNA probes and unlabeled competitors were prepared by annealing oligonucleotides and performing fill-in reactions with the Klenow fragment of DNA polymerase I (GIBCO) according to the manufacturer's instructions and as described. ${ }^{80}$ Our NF- $\kappa$ B probe derived from the FasL gene including the putative NF- $\kappa B$ site is CAGAAAATTGTGGGCGGAAACTTCCAGGGGTTTCGTC and corresponds to the region spanning from -291 to -259 relative to the translation start site. ${ }^{68}$ The NF- $\kappa \mathrm{B}$ binding site competitor is derived from the region I enhancer of the $\mathrm{H}-2 \mathrm{~K}^{\mathrm{b}}$ gene with the sequence CAGGGCTGGGGATTCCCCATCTCCACAGTTTCACTTC. A double point mutant of this site has the sequence CAGGGCTGCGGATTCCCGATCTCCACAGTTTCACTTC. ${ }^{80}$ Mutated bases are in bold and underlined.

\section{Western blots}

Cytoplasmic extracts were prepared as described above. A volume of extract corresponding to $20 \mu \mathrm{g}$ protein was size separated by sodium dodecyl sulfate-10\% polyacrylamide gel electrophoresis (SDS PAGE) and transferred to nitrocellulose by electro-blotting in $25 \mathrm{mM}$ Tris base, $0.2 \mathrm{M}$ glycine, $20 \%$ methanol at $100 \mathrm{~V}$ for $1 \mathrm{~h}$ at $4{ }^{\circ} \mathrm{C}$. The nitrocellulose blot was blocked for 1 to $2 \mathrm{~h}$ in TBST $(10 \mathrm{mM}$ Tris, $150 \mathrm{mM} \mathrm{NaCl}, 0.05 \%$ Tween 20 ) plus $10 \%$ dried milk. FLAGprobe (D8) antibody (Santa Cruz) was diluted 1:2,000 in TBST plus $10 \%$ dried milk for $1 \mathrm{~h}$ at room temperature with gentle shaking. The blot was washed five times for $5 \mathrm{~min}$ each in TBST. An HRP conjugated anti-rabbit IgG antibody (Promega) was diluted 1:10000 in TBST plus $10 \%$ dried milk and the blot incubated with this secondary antibody for $1 \mathrm{~h}$ at room temperature with gentle shaking. The blot was washed five times as described above. The secondary antibody was visualized by electrochemiluminescence (ECL, Amersham) according to the manufacturers instructions and recorded on Kodak XAR5 film.

\section{Extraction and purification of RNA and RT - PCR}

Total RNA was prepared by the acidified phenol method as described. ${ }^{69}$ The mRNA was converted to cDNA utilizing SuperScript II RT (Gibco BRL) with oligo dT (Gibco) as the primer as directed by the manufacturer. Two $\mu$ l of the CDNA was used as template for PCR using primers for mouse FasL: TTCTGGGTAGACAGCAGTGCCACTTCATC and CAGTTTCGTTGATCACAAGGCCACCTTTC or $\beta$ actin: $5^{\prime}$ GATGCATTGTTACAGGAAGT and $3^{\prime}$ TCATACATCTCAAGTTGGGGG. Reaction conditions for FasL amplification were 35 cycles of, melting at $94^{\circ}$ for $30 \mathrm{~s}$, annealing at $65^{\circ}$ for $30 \mathrm{~s}$, and extension at $72^{\circ}$ for $45 \mathrm{~s}$. Reaction conditions for $\beta$-actin amplification were 12 cycles of melting at $94^{\circ}$ for $30 \mathrm{~s}$, annealing at $48^{\circ}$ for $30 \mathrm{~s}$, and extension at $72^{\circ}$ for $45 \mathrm{~s}$. PCR products were separated on a $1 \%$ agarose gel with ethidium bromide and visualized with UV and recorded by Polaroid and scanned.

\section{Apoptosis and cell viability assays}

Apoptosis was assayed using the acridine orange/ethidium bromide double dye technique. ${ }^{71}$ Sample cells were spun down $(900 \times g$, $5 \mathrm{~min})$ and washed with PBS. Two $\mu \mathrm{l}$ of dye $\operatorname{mix}(100 \mu \mathrm{g} / \mathrm{ml}$ acridine orange (Sigma) $+100 \mu \mathrm{g} / \mathrm{ml}$ ethidium bromide in PBS) was placed in the bottom of a $12 \times 75-\mathrm{mm}$ glass tube and $25 \mu \mathrm{l}$ of cell suspension was added to the tube and mixed by hand. Ten $\mu$ of this mixture was placed on a microscope slide and covered with a 22- $\mathrm{mm}^{2}$ cover slip. Samples were examined with a $40 \times$ dry objective using epiillumination and a filter combination suitable for observing 
fluorescein. One hundred cells were counted per sample and the number of cells in each of the following four states was recorded: VNviable normal (bright green chromatin with organized structure), VAviable apoptotic (bright green chromatin that is condensed or fragmented), NVN-non-viable normal cells (bright orange chromatin with organized structure), NVA-non-viable apoptotic (bright orange chromatin that is condensed or fragmented). Per cent apoptosis was then calculated using the following formula: VA+NVA/100=\% apoptosis.

Cell viability was assayed using trypan blue exclusion. A $100 \mu \mathrm{l}$ aliquot of cells was taken and mixed with $100 \mu \mathrm{l}$ of trypan blue solution $(0.1 \%$ in PBS). A $10 \mu \mathrm{l}$ aliquot was placed on a hemocytometer and number of viable cells (clear) and non-viable cells (dark blue) were counted. Results were expressed as a percentage of cells counted.

\section{${ }^{51}$ Chromium labeling and release assay}

Fas expressing L1210-Fas cells to be used as targets in ${ }^{51} \mathrm{Cr}$ release assays were suspended at $1-5 \times 10^{6}$ in $100 \mu \mathrm{l}$ of RPMl 1640 medium with $5 \%$ heat inactivated FBS (R5) to which $100 \mu \mathrm{C}$ of ${ }^{51} \mathrm{Cr}$ in $\mathrm{R} 5$ were added. The cells were then incubated for $90 \mathrm{~min}$ at $37^{\circ} \mathrm{C}$, washed twice in $\mathrm{R} 5$, resuspended in $10 \mathrm{ml}$ of $\mathrm{R} 5$, and incubated at $37^{\circ} \mathrm{C}$ for $30 \mathrm{~min}$. They were washed once more, resuspended in $\mathrm{R} 5$, and counted. The labeled cells $\left(10^{4}\right.$ in $\left.100 \mu \mathrm{l}\right)$ were placed in individual wells of 96-well V-bottomed microtiter plates that contained various concentrations of effector cells in triplicate in $100 \mu \mathrm{l}$ of R5. The plates were centrifuged $(50 \times \mathrm{g} ; 5 \mathrm{~min})$ to establish cell contact and incubated at $37^{\circ} \mathrm{C}$ for $18 \mathrm{~h}$ prior to harvest. At the end of the incubation period, the plates were centrifuged at $100 \times \mathrm{g}$ for $10 \mathrm{~min}$ and $100 \mu \mathrm{l}$ of cell-free supernatant was collected from each well. Radioactivity in supernatants were measured in a gamma counter. Per cent specific release was calculated by the following formula:

$$
\% \text { specific }{ }^{51} \mathrm{Cr} \text { release }=\frac{\text { c.p.m. } \mathrm{m}_{\exp }-\text { c.p.m. } \mathrm{m}_{\text {spont }}}{\text { c.p. } \mathrm{m}_{\max }-\text { c.p.m. } \mathrm{m}_{\text {spont }}} \times 100
$$

Maximal release (c.p.m.max) was determined from supernatants of cells that were subjected to $1 \%$ Triton-X. Spontaneous release (c.p.m.spont) was determined from target cells incubated without added effector cells. ${ }^{81}$

\section{Acknowledgements}

This work was supported through grants to RIS from the Arthritis Foundation, the Cancer League of Colorado, the Burroughs Wellcome Fund, the American Association of Colleges of Pharmacy, the Lupus Foundation of America, and the Colorado Advanced Technology Institute. RCD is supported by USPHS-NIH grants Al40394, Al40607, and CA46934.

\section{References}

1. Sprent J, Lo D, Gao EK and Ron Y (1988) T cell selection in the thymus. Immunol. Rev. 101: 172-190.

2. Kabelitz D, Pohl T and Pechhold K (1993) Activation-induced cell death (apoptosis) of mature peripheral T lymphocytes. Immunol. Today 14: $338-$ 339.

3. Ashwell JD, Longo DL and Bridges SH (1987) T-cell tumor elimination as a result of T-cell receptor-mediated activation. Science 237: 61-64.

4. Mercep M, Bluestone JA, Noguchi PD and Ashwell JD (1988) Inhibition of transformed T cell growth in Vitro by Monoclonal Antibodies Directed against Distinct Activating Molecules. J. Immunol. 140: 324-335.
5. Shi Y, Sahai BM and Green DR (1989) Cyclosporin A inhibits activation-induced cell death in T-cell hybridomas and thymocytes. Nature 339: 625-626.

6. Ucker DS, Ashwel1 JD and Nickas G (1989) Activation-induced T Cell Death I. Requirements for de Novo Transcription and Translation and Association with Genome Fragmentation. J. Immunol. 143: 3461-3469.

7. Shi YF, Szalay MG, Paskar L, Sahai BM, Boyer M, Singh B and Green DR (1990) Activation-Induced Cell Death in T Cell Hybridomas is Due to Apoptosis. Morphologic aspects and DNA fragmentation. J. Immunol. 144: 3326-3333.

8. Zacharchuk CM, Mercep M and Ashwell JD (1990) Programmed T lymphocyte death: cell activation- and steroid-induced pathways are mutually antagonistic. J. Immunol. 145: 4037-4045.

9. Iwata M, Hanaoka S and Sato K (1991) Rescue of thymocytes and T cell hybridomas from glucocorticoid-induced apoptosis by stimulation via the $T$ cell receptor/CD3 complex: a possible in vitro model for positive selection of the T cell repertoire. Eur. J. Immunol. 21: 643-648.

10. Vacchio MS, Papadopoulos V and Ashwell JD (1994) Steroid production in the thymus: implications for thymocyte development. J. Exp. Med. 179: 1835-1846.

11. King LB, Vacchio MS, Hunziker R, Margulies DH and Ashwell JD (1995) A targeted glucocorticoid receptor antisense transgene increases thymocyte apoptosis and alters thymocyte development. Immunity 5: 647-656.

12. Yang Y, Mercep M, Ware CF and Ashwell JD (1995) Fas and Activation-induced Fas Ligand Mediate Apoptosis of T Cell Hybridomas: Inhibition of Fas Ligand Expression by Retinoic Acid and Glucocorticoids. J. Exp. Med. 181: 1673- 1682.

13. Russell JH, Rush B, Weaver C and Wang R (1993) Mature T cells of autoimmune Ipr/lpr mice have a defect in antigen-stimulated suicide. Proc. Natl. Acad. Sci. USA 90: 4409-4413.

14. Russell JH and Wang R (1993) Autoimmune gld mutation uncouples suicide and cytokine/proliferation pathways in activated mature T cells. Eur. J. Immunol. 23: 2379-2382.

15. Nagata S and Golstein $P$ (1995) The Fas death factor. Science 267: 1449-1456.

16. Dhein J, WalczakH, BaumlerC, Debatin KMand KrammerPH (1995) Autocrine T cell suicide mediated by APO-1(Fas/CD95). Nature 373: 438-441.

17. Brunner T, Mogil RJ, LaFace D, Yoo NJ, Mahoubl A, Echeverri F, Martin SJ, Force WR, Lynch DH, Ware CF and Green DR (1995) Cell-autonomous Fas (CD95)/Fas-ligand interaction mediates activation-induced apoptosis in T-cell hybridomas. Nature 373: $441-444$.

18. Ju S-T, Panka DJ, Cul H, Ettinger R, El Khatib M, Sheh DH, Stanger BZ and Marshak-Rothstein A (1995) Fas (CD95)/FasL interactions required for programmed cell death after T-cell activation. Nature 373: 444-448.

19. Chinnaiyan AM and Dixit VM (1996) The Cell-Death Machine. Current Biology 6 : $555-562$.

20. Peter ME, Heufelder AE and Hengartner MO (1997) Advances in Apoptosis Research. Proc. Natl. Acad. Sci. USA 94: 12736-12737.

21. Nagata S (1997) Apoptosis by Death Factor. Cell 88: 355-365.

22. Boldin MP, Varfolomeev EE, Pancer Z, Mett IL, Camonis JH and Wallach D (1995) A novel protein that interacts with the death domain of Fas/APO1 contains a sequence motif related to the death domain. J. Biol. Chem. 270: 7795-7798.

23. Chinnaiyan AM, O'Rourke K, Tewari M and Dixit VM (1995) FADD, a novel death domain-containing protein, interacts with the death domain of Fas and initiates apoptosis. Cell. 81: 505-512.

24. Boldin MP, Goncharov TM, Goltsev YV, Wallach D (1996) Involvement of MACH, a novel MORT1/FADD-interacting protease, in Fas/APO-1- and TNF receptorinduced cell death. Cell. 85: 803-815.

25. Muzio M, Chinnaiyan AM, Kischkel FC, O'Rourke K, Shevchenko A, Ni J, Scaffidi C, Bretz JD, Zhang M, Gentz R, Mann M, Krammer PH, Peter ME, Dixit VM (1996) FLICE, a novel FADD-homologous ICE/CED-3-like protease, is recruited to the CD95 (Fas/APO-1) death-inducing signaling complex. Cell 85: 817-827.

26. Hsu H, Xiong J and Goeddel DV (1995) The TNF receptor 1-associated protein TRADD signals cell death and NF-kappa B activation. Cell 81: 495-504.

27. Stanger BZ, Leder P, Lee TH, Kim E and Seed B (1995) RIP: a novel protein containing a death domain that interacts with Fas/APO-1 (CD95) in yeast and causes cell death. Cell. 81: 513-523.

28. Hsu H, Shu HB, Pan MG and Goeddel DV (1996) TRADD-TRAF2 and TRADDFADD interactions define two distinct TNF receptor 1 signal transduction pathways. Cell 84: 299-308.

29. Rothe M, Wong SC, Henzel WJ and Goeddel DV (1994) A novel family of putative signal transducers associated with the cytoplasmic domain of the $75 \mathrm{kDa}$ tumor necrosis factor receptor. Cell 78: 681-692.

30. Baeuerle PA and Henkel T (1994) Function and activation of NF- $k$ B in the immune system. Annu. Rev. Immunol. 12: 141-179. 
31. Baldwin Jr AS (1996) The NF-kappa B and I kappa B proteins: new discoveries and insights. Annual Review of Immunology. 14: 649-683.

32. Kunsch C, Ruben SM, Rosen CA (1992) Selection of optimal kappa B/Rel DNAbinding motifs: interaction of both subunits of NF-kappa B with DNA is required for transcriptional activation. Mol. Cell. Biol. 12: 4412-4421.

33. Mercurio F, Zhu H, Murray BW, Shevchenko A, Bennett BL, Li J, Young DB, Barbosa M, Mann M, Manning A and Rao A (1997) IKK-1 and IKK-2: cytokineactivated IkappaB kinases essential for NF-kappaB activation. Science 278: $860-866$.

34. Woronicz JD, Gao X, Cao Z, Rothe M and Goeddel DV IkappaB kinase-beta: NF$\mathrm{kB}$ activation and complex formation with IkappaB kinase-alpha and NIK. Science 278: 866-869.

35. ZandiE, RothwarfDM, Delhase M, Hayakawa Mand Karin M(1997) The lkappaB kinase complex (IKK) contains two kinase subunits, IKKalpha and IKKbeta, necessary for IkappaB phosphorylation and NF-kappaB activation. Cell 91: $243-252$

36. Beg AA, Sha WC, Bronson RT, Ghosh S and Baltimore D (1995) Embryonic lethality and liver degeneration in mice lacking the RelA component of NF- $\kappa$ B. Nature 376: 167-170.

37. Beg AA and Baltimore D (1996) An essential role for NF-kappaB in preventing TNF-alpha-induced cell death. Science 274: 782-784.

38. Van Antwerp DJ, Martin SJ, Kafri T, Green DR, Verma IM (1996) Suppression of TNF-alpha-induced apoptosis by NF-kappaB. Science 274: 787-789.

39. Liu ZG, Hsu H, Goeddel DV and Karin M (1996) Dissection of TNF receptor 1 effector functions: JNK activation is not linked to apoptosis while NF-kappaB activation prevents cell death. Cell 87: 565-576.

40. Chinetti G, Griglio S, Antonucci M, Torra IP, Delerive P, Majd Z, Fruchart JC, Chapman J, Najib J and Staels B (1998) Activation of proliferator-activated receptors alpha and gamma induces apoptosis of human monocyte-derived macrophages. J. Biol. Chem. 273: 25573-25580.

41. Wang CY, Mayo MW and Baldwin Jr AS (1996) TNF-and cancer therapy-induced apoptosis: potentiation by inhibition of NF-kappaB. Science 274: 784-787.

42. Mayo MW, Wang CY, Cogswell PC, Rogers-Graham KS, Lowe SW, Der CJ and Baldwin Jr AS (1997) Requirement of NF- $k$ B activation to suppress p53independent apoptosis induced by oncogenic Ras. Science 278: 1812-1815.

43. Wang CY, Mayo MW, Korneluk RG, Goeddel DV and Baldwin Jr AS (1998) NFkappaB antiapoptosis: induction of TRAF1 and TRAF2 and c-IAP1 and c-IAP2 to suppress caspase-8 activation. Science 281: 1680-1683.

44. Wu MX, AoZ, Prasad KV, Wu R and Schlossman SF (1998) IEX-1L, an apoptosis inhibitor involved in NF-kappaB-mediated cell survival. Science 281:998-1001.

45. Arsura M, Wu M and Sonenshein GE (1996) TGF $\beta 1$ inhibits NF- $\kappa$ B/Rel activity inducing apoptosis of $B$ cells: Transcriptional Activation of $\left.\right|_{\kappa} \mathrm{B} \alpha$. Immunity $5: 31$ 40.

46. Schauer SL, Bellas RE, Sonenshein GE (1998) Dominant signals leading to inhibitor kappaB protein degradation mediate CD40 ligand rescue of WEHI 231 immature B cells from receptor-mediated apoptosis. J. Immunol. 160: 43984405 .

47. Abbadie C, Kabrun N, Bouali F, Smardova J, Stehelin D, Vandenbunder B and Enrietto PJ (1993) High levels of c-rel expression are associated with programmed cell death in the developing avian embryo and in bone marrow cells in vitro. Cell 75: 899-912.

48. Kitajima I, Soejima Y, Takasaki I, Beppu H, Tokioka T and Maruyama I (1996) Ceramide-induced nuclear translocation of $\mathrm{NF}-\kappa \mathrm{B}$ is a potential mediator of the apoptotic response to TNF $\alpha$ in murine clonal osteoblasts. Bone 19: 263-270.

49. Hunot S, Brugg B, Ricard D, MichelPP, Muriel MP, Ruberg M, Faucheux BA, Agid $Y$ and Hirsch EC (1997) Nuclear translocation of NF- $k B$ is increased in dopaminergic neurons of patients with parkinson disease. Proc. Natl. Acad. Sci. U.S.A. $94: 7531-7536$

50. Lin K-I, Lee S-H, Narayanan R, Baraban JM, Hardwick JM and Ratan RR (1995) Thiol agents and $\mathrm{Bcl}-2$ identify an alphavirus-induced apoptotic pathway that requires activation of the transcription factor NF- $\kappa$ B. J. Cell Biol. 131: 11491161.

51. Marianneau P, Cardona A, Edelman L, Deubel V and Despres P (1997) Dengue virus replication in human hepatoma cells activates NF- $\kappa$ B which in turn induces apoptotic cell death. J. Virol. 71: $3244-3249$.

52. Lipton SA and Rosenberg PA (1994) Mechanisms of disease: Excitatory amino acids as a final common pathway for neurologic disorders. N. Eng. J. Med. 330: $613-622$.
53. Grilli M, Pizzi M, Memo M and Spano P (1996) Neuroprotection by aspirin and sodium salicylate through blockade of NF- $\kappa$ B activation. Science 274 : 13831385.

54. Qin ZH, Wang Y, Nakai M and Chase TN (1998) Nuclear factor-kappa B contributes to excitotoxin-induced apoptosis in rat striatum. Mol. Pharmacol. 53: $33-42$.

55. Moore NC, Girdlestone J, Anderson G, Owen JJ and Jenkinson EJ (1995) Stimulation of thymocytes before and after positive selection results in the induction of different NF-kappa B/Rel protein complexes. J. Immunol. 155: 4653-4660.

56. Jain J, Loh C and Rao A (1995) Transcriptional regulation of the IL-2 gene. Curr. Opin. Immunol. 7: 333-342.

57. Maggirwar SB, Harhaj EW and Sun SC (1997) Regulation of the interleukin-2 CD28-responsive element by NF-ATp and various NF-kappaB/Rel transcription factors. Mol. Cell. Biol. 17: 2605-2614.

58. Gerondakis S, GrumontR, Rourke land Grossmann M(1998) The regulation and roles of Rel/NF-kappa B transcription factors during lymphocyte activation. Curr. Opin. Immunol. 10: 353-359.

59. Brockman JA, SchererDC, McKinsey TA, Hall SM, QiX, Lee WY and Ballard DW (1995) Coupling of a signal response domain in $\mathrm{I}_{\kappa} \mathrm{B} \alpha$ to multiple pathways for NF. $\kappa$ B activation. Mol. Cell. Biol. 15: 2809-2818.

60. Brown K, Gerstberger S, Carlson L, Franzoso G and Siebenlist U (1995) Control of I kappa B-alpha proteolysis by site-specific, signal-induced phosphorylation. Science. 267: 1485-1488

61. Boothby MR, Mora AL, Scherer DC, Brockman JA and Ballard DW (1997) Perturbation of the $T$ lymphocyte lineage in transgenic mice expressing a constitutive repressor of nuclear factor (NF)-kappaB. J. Exp. Med. 185: $1897-$ 1907.

62. Ray A and Prefontaine KE (1994) Physical association and functional antagonism between the p65 subunit of transcription factor NF-kappa B and the glucocorticoid receptor. Proc. Natl. Acad. Sci. USA 91: 752-756.

63. Scheinman RI, Gualberto A, Jewell CM, Cidlowski JA and Baldwin Jr AS (1995) Characterization of the Mechanisms Involved in the Transrepression of NF- $\kappa$ B by Activated Glucocorticoid Receptors. Mol. Cell Biol. 15: 943-953.

64. Caldenhoven E, Liden J, Wissink S, Van de Stolpe A, Raaijmakers J, Koenderman L, Okret S, Gustafsson JA and Van der Saag PT (1995) Negative cross-talk between RelA and the glucocorticoid receptor: a possible mechanism for the antiinflammatory action of glucocorticoids. Molecular Endocrinology 9: $401-412$.

65. Scheinman RI, Cogswell PC, Lofquist AK and Baldwin Jr AS (1995) Role of transcriptional activation of $\mid \kappa \mathrm{B} \alpha$ in mediation of immunosuppression by glucocorticoids. Science 270: 283-286.

66. Auphan N, DiDonato JA, Rosette C, Helmberg A and Karin M (1995) Immunosuppression by glucocorticoids: inhibition of NF- $\kappa$ B activity through induction of $I_{\kappa} B$ synthesis. Science 270: $232-233$.

67. De Bosscher K, Schmitz ML, Vanden-Berghe W, Plaisance S, Fiers W and Haegeman G (1997) Glucocorticoid-mediated repression of nuclear factorkappaB-dependent transcription involves direct interference with transactivation. Proc. Natl. Acad. Sci. USA 94: 13504-13509.

68. Takahashi T, Tanaka M, Inazawa J, Abe T, Suda T and Nagata S (1994) Human Fas ligand: gene structure, chromosomal location and species specificity. Int. Immunol. 6: 1567-1574.

69. Chomczynski Pand SacchiN (1987) Single-step method of RNA isolation by acid guanidinium thiocyanate-phenol-chloroform extraction. Analytical Biochemistry 162: $156-159$.

70. Kasibhatla S, Brunner T, Genestier L, Echeverri F, Mahboubi A and Green DR (1998) DNA damaging agents induce expression of Fas ligand and subsequent apoptosis in T lymphocytes via the activation of NF-kappa B and AP-1. Mol. Cell 1: $543-551$.

71. Duke RC and Cohen JJ (1991) Quantitation of apoptotic index and cell viability using fluorescent dyes. In Current Protocols in Immunology JE Coligan, AM Kruisbeck, DH Marguiles, EM Sevach and W Strober eds. New York: Green Publishing and Wiley-Interscience pp3.17.1-3.17.3.

72. Chen X, Zachar V, Zdravkovic M, Guo M, Ebbesen P and Liu X (1997) Role of the Fas/Fas ligand pathway in apoptotic cell death induced by the human $T$ cell lymphotropic virus type I Tax transactivator. J. Gen. Virol. 78: 3277-3285. 
73. Cui H, Matsui K, Omura S, Schauer SL, Matulka RA, Sonenshein GE and Ju ST (1997) Proteasome regulation of activation-induced T cell death. Proc. Natl. Acad. Sci. USA 94: 7515-7520.

74. Latinis KM, Norian LA, Elision SL and Koretzky GA (1997) Two NFAT transcription factor binding sites participate in the regulation of CD95(Fas) ligand expression in activated human T cells. J. Biol. Chem. 272: 31427-31434.

75. Ponton A, Clement MV and Stamenkovic I (1996) The CD95 (APO-1/Fas) receptor activates NF-kappaB independently of its cytotoxic function. J. Biol. Chem. 271: $8991-8995$

76. Ravi R, Bedi A, Fuchs EJ and Bedi A (1998) CD95 (Fas)-induced caspasemdiated proteolysis of NF- $\kappa$ B. Cancer Res. 58: 882-886.

77. Zong WX, Bash J and Gelinas C (1998) Rel blocks both anti-Fas- and TNF alphainduced apoptosis and an intact Rel transactivation domain is essential for this effect. Cell Death Differ. 5: 963-972.
78. Chu ZL, McKinsey TA, Liu L, Gentry JJ, Malim MH and Ballard DW (1997) Suppression of tumor necrosis factor-induced cell death by inhibitor of apoptosis c-IAP2 is under NF-kappaB control. Proc. Natl. Acad. Sci. USA 94: 1005710062.

79. Bradford MM (1976) A Rapid and Sensitive Method for the Quantitation of Microgram Quantities of Protein Utilizing the Principle of Protein-dye binding. Anal. Biochem. 72: 248-254.

80. Scheinman RI, Beg AA and Baldwin AS (1993) NF- $k$ B p100 (lyt-10) is a Component of H2TF1 and Can Function as an $l_{\kappa}$ B-Like Molecule. Mol. Cell. Biol. 13: $6089-6101$.

81. Duke RC, Chervenak R and Cohen JJ (1983) Endogenous endonucleaseinduced DNA fragmentation: an early event in cell-mediated cytolysis. Proc. Natl. Acad. Sci. USA 80: 6361-6365. 